\title{
Development of vaccines against Burkholderia pseudomallei
}

\section{Natasha Patel ${ }^{1}$ *, Laura Conejero ${ }^{1}$, Melanie De Reynal ${ }^{1}$, Anna Easton ${ }^{2}$, Gregory J. Bancroft ${ }^{1}$ and Richard W. Titball ${ }^{3}$}

1 Department of Immunology and Infection, London School of Hygiene and Tropical Medicine, London, UK

${ }^{2}$ Centre for Clinical Microbiology, Department of Infection, Royal Free Campus, University College London, UK

${ }^{3}$ College of Life and Environmental Sciences, University of Exeter, Exeter, UK

\section{Edited by:}

Ivo Steinmetz, University of

Greifswald, Germany

Reviewed by:

Robert Norton, Townsville Hospital,

Australia

Joost Wiersinga, Academic Medical

Center, Netherlands

\section{*Correspondence:}

Natasha Patel, Immunology Unit,

London School of Hygiene and

Tropical Medicine, Keppel Street,

London WC1E 7HT, UK.

e-mail: natasha.spink@Ishtm.ac.uk
Burkholderia pseudomallei is a Gram-negative bacterium which is the causative agent of melioidosis, a disease which carries a high mortality and morbidity rate in endemic areas of South East Asia and Northern Australia. At present there is no available human vaccine that protects against $B$. pseudomallei, and with the current limitations of antibiotic treatment, the development of new preventative and therapeutic interventions is crucial. This review considers the multiple elements of melioidosis vaccine research including: (i) the immune responses required for protective immunity, (ii) animal models available for preclinical testing of potential candidates, (iii) the different experimental vaccine strategies which are being pursued, and (iv) the obstacles and opportunities for eventual registration of a licensed vaccine in humans.

Keywords: vaccines, melioidosis, Burkholderia pseudomallei

\section{BURKHOLDERIA PSEUDOMALLEI AND MELIOIDOSIS}

Burkholderia pseudomallei is a Gram-negative, facultative intracellular bacterium which can infect humans and a wide variety of animals (Cheng and Currie, 2005). Natural infection is thought to be primarily via percutaneous inoculation following exposure to muddy soils or surface water, such as in rice paddy fields, in endemic areas (Currie, 2003). It is thought that under certain environmental conditions, such as tropical storms, cyclones, and typhoons, inhalation is the main mode of infection (Currie, 2008). The incidence of melioidosis in endemic areas increases during the monsoon season and is associated with severe infection, pneumonia, and high mortality (Chaowagul et al., 1989; Currie and Jacups, 2003). This is analogous to the fulminant disease and high case fatality rates seen when the bacteria causing anthrax, plague, or tularemia are inhaled rather than inoculated (Inglesby et al., 2000, 2002; Dennis et al., 2001). This shift to more severe melioidosis during the rainy season could be explained by increased exposure to $B$. pseudomallei, possibly due to the heavy rain and winds generating aerosols, causing repeated inhalation of contaminated particles and a greater infection dose (Wiersinga et al., 2006). As this bacterium can cause disease following inhalation and is difficult to treat with antibiotics, it is now considered as a bioterrorism threat and as a potential agent for biological warfare it was added to the list of category B agents by the US Centers for Disease Control and Prevention.

Melioidosis is difficult to treat as B. pseudomallei is intrinsically resistant to many antibiotics (Wiersinga et al., 2006). However, this bacterium is susceptible to some newer $\beta$-lactam antibiotics and especially ceftazidime (McEniry et al., 1988; Dance et al., 1989; White, 2003). Despite the long course of treatment (typically 20 weeks), the mortality rate in endemic areas remains high $(40-50 \%)$ and recurrence is common, the overall risk being $10 \%$ and rising to $30 \%$ if treatment lasts less than 8 weeks (Chaowagul et al., 1993). Of those recurrent infections, $75 \%$ are due to bacteria persisting from the original infection, and the remainder are due to re-infection with a different strain (Limmathurotsakul et al., 2006, 2007). Approximately $25 \%$ of patients who experience a recurrence die (Chaowagul et al., 1993). At present there is no available human vaccine that protects against $B$. pseudomallei, and with the current limitations of antibiotic treatment, the development of new therapeutic strategies is crucial.

\section{HOST IMMUNE RESPONSES TO B. PSEUDOMALLEI}

Development of new vaccines against melioidosis will benefit from a thorough understanding of the pathogenesis of infection and the characteristics of naturally occurring immune responses which develop following environmental or experimental exposure to the organism. In this section we review what is known about immune responses generated against $B$. pseudomallei, based primarily on data obtained from mouse models of experimental infection and studies in humans living in the endemic regions of North Eastern (NE) Thailand and Northern Australia.

\section{INNATE IMMUNITY}

An efficient host immune response is reliant on both fast acting innate immunity, as well as the more specific but slower adaptive immunity. Innate immunity is a universal and ancient form of host defense, and is essentially the "front line" against infection as it is these effector cells which first come into contact with and respond to invading microorganisms (Janeway and Medzhitov, 2002).

A key element in the initiation of an effective innate immune response and subsequent adaptive immunity is the recognition of microbes by innate cells. Pathogen recognition is mediated 
by pattern recognition receptors (PRRs) located on or within host cells, which bind to pathogen associated molecular patterns (PAMPs) expressed by microorganisms (Akira et al., 2006). A large family of well characterized PRRs are the toll-like receptors (TLRs; Akira et al., 2006). B. pseudomallei expresses a number of potential PAMPs including, lipopolysaccharide (LPS), lipid-A, peptidoglycan, flagellin, type III secretion system (TTSS), and DNA, which have the potential to be recognized by different TLRs (Wiersinga and van der Poll, 2009). Mice lacking a key TLR adaptor signaling protein (MyD88) are highly susceptible to B. pseudomallei infection, partly due to reduced recruitment and activation of neutrophils (Wiersinga et al., 2008). TLR4 is thought to be a key molecule in protection against Gram-negative bacteria, given it is the main receptor for LPS (Akira et al., 2006). However a relatively recent study has shown TLR4 does not contribute to host defense against melioidosis in vivo (Wiersinga et al., 2007b). The LPS from B. pseudomallei differs from other Gram-negative bacteria, and is much less inflammatory (Matsuura et al., 1996), which may contribute to immune evasion. Surprisingly, evidence suggests that B. pseudomallei LPS signals via TLR2 as opposed to TLR4, and that this pathway can in fact exacerbate disease in the host (Wiersinga et al., 2007b). However the mechanism by which TLR2 signaling contributes to B. pseudomallei pathogenesis remains to be determined. Furthermore, increased expression of TLR2 and TLR4 can be seen in patients with septic melioidosis (Wiersinga et al., 2007b). Together this data indicates a protective role for TLR-mediated MyD88-dependent cell signaling, but highlights that dysregulation of TLR-mediated immune responses can result in pathogenesis and contribute to the development of septic melioidosis.

The IFN $\gamma$ response, especially within the first $24 \mathrm{~h}$ of $B$. pseudomallei infection, has proven essential for resistance in mice, as demonstrated by the rapid death of IFN $\gamma \mathrm{KO}$ mice and mice treated with neutralizing monoclonal antibodies (mAb) against IFN $\gamma$ (Santanirand et al., 1999; Haque et al., 2006a; Wiersinga et al., 2007c). These studies also showed the IFN $\gamma$-inducing cytokines IL-12, and to a lesser extent IL-18, are essential for resistance to infection (Santanirand et al., 1999; Haque et al., 2006a). The cellular source of IFN $\gamma$ is primarily NK cells and bystander-activated $\mathrm{CD}^{+}{ }^{+} \mathrm{T}$ cells (Lertmemongkolchai et al., 2001), but these cells do not appear to be crucial in early protection suggesting extensive redundancy in the source of IFN $\gamma$ (Haque et al., 2006a). In the absence of NK cells and T cells, up to $5 \%$ of the IFN $\gamma$ response can still be detected and surprisingly this is still sufficient to initially control the infection. This compensation in IFN $\gamma$ production has been attributed to non-lymphoid cells such as macrophages (Haque et al., 2006a).

IFN $\gamma$ activated macrophages contribute to host defense by phagocytosis and killing of microbes via production of reactive oxygen intermediates (ROIs) and reactive nitrogen intermediates (RNIs), as well as cytokine and chemokine production, and antigen-presentation to T cells (Taylor et al., 2005). In vivo studies have provided evidence that macrophages are essential for early control of B. pseudomallei in both BALB/c and C57BL/6 mice (Breitbach et al., 2006). Although several immune evasion strategies have been described including inhibition of iNOS and TNF $\alpha$ production, upregulation of the suppressor of cytokine signaling 3
(SOCS3) and cytokine-inducible Src homology 2-containing protein (CIS), resulting in reduced IFN $\gamma$ signaling (Utaisincharoen et al., 2001; Ekchariyawat et al., 2005). Furthermore there may be distinct roles for nitric oxide (NO) between mouse strains as $\mathrm{BALB} / \mathrm{c}$ mice were more susceptible to early infection when NO was inhibited, whereas $\mathrm{C} 57 \mathrm{BL} / 6$ iNOS $^{-1-}$ mice showed the same disease progression as wild-type controls (Breitbach et al., 2006, 2011).

Neutrophils or polymorphonuclear leukocytes (PMNLs) are the first cells to arrive at the site of infection and are potent effectors of innate immune responses, both by direct antimicrobial activity and through the induction of inflammatory responses via immuno-regulatory cytokine and chemokine production (Scapini et al., 2000; Segal, 2004; Martineau et al., 2007). Following intravenous (i.v.) challenge with $B$. pseudomallei, upregulation of the neutrophil chemokines CXCL1 (KC) and CXCL2 (MIP2) can be detected in mouse spleen and liver tissues, coinciding with neutrophil infiltration to the site of infection (Barnes et al., 2001). In vivo depletion of these cells using neutralizing $\mathrm{mAb}$, resulted in exacerbated disease mortality as mice were unable to control bacterial burdens compared to untreated mice, suggesting an essential role for neutrophils in early resistance to experimental pulmonary B. pseudomallei infection (Easton et al., 2007). Neutrophils are a major source of ROIs, and this is the principle microbicidal mechanism employed by these cells. There is evidence to suggest ROIs may contribute to resistance as mice lacking NADPH oxidase, an important enzyme in the generation of ROIs, were more susceptible to B. pseudomallei infection (Breitbach et al., 2006). Conversely, in vitro studies have demonstrated conflicting abilities of isolated human PMNLs to kill $B$. pseudomallei (Egan and Gordon, 1996; Chanchamroen et al., 2009).

Overall the literature involving neutrophils in human melioidosis is limited. Biopsies from melioidosis patients revealed necrotic lesions with extensive neutrophil infiltration and higher numbers of neutrophils have been detected in peripheral blood samples from melioidosis patients compared to healthy controls (Piggott and Hochholzer, 1970; Wong et al., 1995; Ramsay et al., 2002). In accordance with this, expression of the human neutrophil chemokine CXCL8 (IL-8) is induced following the infection of human cells with $B$. pseudomallei and serum levels of IL- 8 may be an indicator of poor prognosis in human melioidosis (Friedland et al., 1992; Utaisincharoen et al., 2004; Hii et al., 2008). Defective neutrophil function has been linked to the increased susceptibility seen in diabetic patients, a prominent risk factor of melioidosis, highlighting the importance of these cells in resistance to disease (Chanchamroen et al., 2009). Furthermore, melioidosis has been reported in chronic granulomatous disease (CGD) patients, a condition characterized by defective NADPH oxidase (Dorman et al., 1998; Renella et al., 2006).

From these studies it is clear that early control of B. pseudomallei infection is paramount for survival, however the underlying mechanisms of innate protection remain unclear. Considering the important interactions between the innate and adaptive immune systems, further understanding of innate resistance will be beneficial to the development of therapeutic agents against $B$. pseudomallei. 


\section{T CELL-MEDIATED IMMUNITY}

There is an extensive literature on the role of $\mathrm{CD} 4^{+}$and $\mathrm{CD} 8^{+}$ $\mathrm{T}$ cells in immunity to other pathogenic bacteria (Coffman and Carty, 1986; Mosmann et al., 1986; Edelson and Unanue, 2000; Flynn and Chan, 2001), but to date such information in the context of melioidosis is limited. Studies using mice have demonstrated that $\mathrm{T}$ cell-mediated immunity (CMI) is necessary for protection against disease. Following i.v. B. pseudomallei infection in mice, delayed-type hypersensitivity (DTH) responses and lymphocyte proliferation to $B$. pseudomalle $i$ were detected, indicating the generation of CMI and memory cells (Barnes and Ketheesan, 2007). A study by Haque et al. found $\mathrm{RAG}^{-/-}$mice, which lack T and $\mathrm{B}$ cells, succumbed to infection via the i.p. route more rapidly than C57BL/6 wild-type mice. T cells isolated from infected C57BL/6 mice demonstrated Ag-specific IFN $\gamma$ production in response to restimulation in vitro, suggesting primary infection with $B$. pseudomallei primes populations of memory $\mathrm{CD} 4^{+}$and $\mathrm{CD} 8^{+} \mathrm{T}$ cells. Further analysis of the $\mathrm{T}$ cell compartment by depletion of $\mathrm{CD} 4^{+}$ or $\mathrm{CD}^{+} \mathrm{T}$ cells before intraperitoneal (i.p.) challenge and for 50 days post infection, showed mice lacking $\mathrm{CD} 4^{+} \mathrm{T}$ cells died significantly earlier than controls (Haque et al., 2006a). Mice depleted of $\mathrm{CD}^{+} \mathrm{T}$ cells also had a shorter survival time compared to controls, however the difference was not statistically significant suggesting $\mathrm{CD}^{+}{ }^{+} \mathrm{T}$ cells play a more important role in protection against B. pseudomallei infection (Haque et al., 2006a). Despite in vitro studies showing early $\mathrm{CD}^{+} \mathrm{T}$ cell-derived IFN $\gamma$ production due to bystander activation (Lertmemongkolchai et al., 2001), the contribution of $\mathrm{T}$ cells to resistance is essential only in the later stages of infection. This is demonstrated by the fact that $\mathrm{RAG}^{-1-}$ mice were able to control early bacterial growth as efficiently as wild-type controls but still succumbed to infection after 14 days, consistent with the time course of activation of the adaptive immune response (Haque et al., 2006a).

There is increasing evidence of the induction of B. pseudomallei-reactive $\mathrm{T}$ cells in humans. Lymphocytes from patients who had recovered from clinical melioidosis and patients who were seropositive but had no clinical history of disease, were able to proliferate in vitro in response to B. pseudomallei (Ketheesan et al., 2002; Barnes et al., 2004; Govan and Ketheesan, 2004). The proliferative response was significantly higher in these patients when compared to seronegative healthy controls. Further analysis of these lymphocytes showed the $\mathrm{CD}^{+}$and $\mathrm{CD}^{+} \mathrm{T}$ cells were activated and capable of producing antigenic-specific IFN $\gamma$ (Ketheesan et al., 2002; Barnes et al., 2004). The percentage of each $\mathrm{T}$ cell subtype and IFN $\gamma$ production was significantly higher in recovered patients compared to controls suggesting the presence of B. pseudomallei-reactive memory T cells (Ketheesan et al., 2002; Barnes et al., 2004). In contrast patients with acute melioidosis are known to be lymphocytopenic with low numbers of circulating $\mathrm{CD}^{+}$and $\mathrm{CD}^{+}{ }^{+} \mathrm{T}$ cells, possibly compromising the development of specific immunity (Tanphaichitra and Srimuang, 1984; Ramsay et al., 2002).

A recent study on Thai patients who had recovered from melioidosis, identified IFN $\gamma$-producing $\mathrm{CD}^{+}{ }^{+}$and $\mathrm{CD} 8^{+} \mathrm{T}$ cells which recognized LolC, OppA, and PotF, which are members of the $B$. pseudomallei ATP-binding cassette $(\mathrm{ABC})$ transporter family and are known T cell immunogens in mice (Tippayawat et al., 2009).
These antigen-specific $\mathrm{T}$ cells were responsible for the majority of the total IFN $\gamma$ generated in the culture, as T cell depletion significantly reduced the IFN $\gamma$ ELISPOT response. A strong correlation between IFN $\gamma$ and granzyme B was also observed by ELISPOT, indicating cytotoxic $\mathrm{CD}^{+} \mathrm{T}$ cells are primed in response to $B$. pseudomallei (Tippayawat et al., 2009). Further characterization of these memory $\mathrm{T}$ cells revealed the majority were terminally differentiated T effector memory cells (Tippayawat et al., 2009). These data suggest memory $\mathrm{T}$ cells are capable of recognizing and rapidly responding to $B$. pseudomallei antigens, but do not prove this response is protective. However, seropositive individuals with no clinical history of disease showed a higher proliferative and IFN $\gamma$ response than those who had recovered from clinical melioidosis (Barnes et al., 2004). Together these studies indicate that a strong $\mathrm{T}$ cell response may be essential for resolution of clinical melioidosis and protection against disease progression (Barnes et al., 2004).

The importance of $\mathrm{CD}^{+}{ }^{+} \mathrm{T}$ cells in other pulmonary infections is highlighted by the human immuno-deficiency virus (HIV) epidemic. HIV patients are more susceptible to infection from opportunistic lung pathogens such as M. tuberculosis, Pneumocystis carinii, and Streptococcus pneumoniae, and this increased risk is inversely proportional to the circulating $\mathrm{CD} 4^{+} \mathrm{T}$ cell count (Phair et al., 1990; Hoover et al., 1993; Gilks et al., 1996; Dworkin et al., 2001; Sharma et al., 2005). Surprisingly, the loss of CD4 ${ }^{+} \mathrm{T}$ cells during HIV infection does not appear to be a risk factor for melioidosis (Chierakul et al., 2005), questioning the importance of these cells in protection in human disease despite the clear evidence of their presence in exposed individuals and their role in protection in mouse models. It should also be noted that whilst current literature indicates a role for the Th1 arm of the adaptive immune response, at present the function of other $\mathrm{T}$ cell subsets such as $\mathrm{T}$ reg and Th17 cells during B. pseudomallei infection are unknown.

\section{ANTIBODY-MEDIATED IMMUNITY}

In endemic areas a large proportion of the population are seropositive for antibodies against $B$. pseudomallei, though the functions of these antibodies and their roles in protection are unclear (Cheng et al., 2008). High levels of B. pseudomallei-specific IgG, IgM, and IgA antibodies have been detected in sera from melioidosis patients, which remained elevated for the duration of infection. Further analysis of the IgG isotype revealed IgG1 to be the predominant subclass produced, indicative of a Th1 response. Yet eradication of $B$. pseudomalle $i$ was not evident in these patients as relapse occurred (Vasu et al., 2003). This apparent lack of protective humoral responses during primary infection is also reflected in studies where $\mu \mathrm{MT}$ mice lacking B cells were as susceptible to B. pseudomallei infection as wild-type mice (Haque et al., 2006a). Given that B. pseudomallei is a facultative intracellular pathogen which can spread from cell-to-cell, it may be that the bacteria is protected from antibody killing by remaining inside host cells. The elevated antibody responses observed in melioidosis patients could be directed against extracellular bacteria before they are taken up into host cells. Therefore the generation of these antibodies is ineffective at preventing disease.

In contrast to the suggestions that antibodies play no role in protection, IgG antibodies to B. pseudomallei LPS were 
significantly higher in patients who survived melioidosis compared to those who died, and also higher in patients with nonseptic melioidosis compared to septic patients (Charuchaimontri et al., 1999). This indicates that antibodies against LPS may be protective against disease. In addition, a number of in vivo studies in mice have demonstrated a protective humoral immune response by passive transfer of antibodies to B. pseudomallei components, such as LPS, capsular polysaccharide (CPS), and flagellin (Brett and Woods, 1996; Ho et al., 1997; Jones et al., 2002; Nelson et al., 2004). In these studies, protection was incomplete and mice eventually succumbed to infection (Jones et al., 2002). Antibodies against LPS appear to be protective by promoting opsonizationinduced phagocytic killing of bacteria in vitro (Ho et al., 1997). It is also possible that B cells are required for other functions. For example, it is well known that B cells are efficient at presenting soluble antigens via MHC class II, resulting in the further activation of $\mathrm{CD}^{+} \mathrm{T}$ cells (Janeway et al., 2008). There is evidence that $\mathrm{B}$ cells can amplify the IFN $\gamma$ response by $\mathrm{T}$ cells via a TNF $\alpha-$ mediated mechanism during infection (Menard et al., 2007). This could be important in B. pseudomallei infection as both these cytokines are required for protection (Santanirand et al., 1997, 1999). Furthermore, B cell-deficient mice infected with lymphocytic choriomeningitis virus (LCMV) experienced a loss of CD4 ${ }^{+}$ T cell memory and were subsequently unable to resolve the chronic infection (Thomsen et al., 1996). At present the interactions of B and $\mathrm{T}$ cells during B. pseudomallei infection are not known, and it is possible that these cells could contribute to vaccine-mediated immunity or modulation of chronic infections in addition to antibody production. Hence there is conflicting evidence surrounding the role of B cells and antibodies in resistance to primary B. pseudomallei infection, and further studies are necessary to resolve this debate.

\section{IS A VACCINE AGAINST B. PSEUDOMALLEI POSSIBLE?}

Observations of the epidemiology of human melioidosis can provide important clues to guide vaccination strategies and flag some of the potential obstacles that may arise in development of an effective product. In endemic rural areas a large proportion of the population may be exposed to $B$. pseudomallei and will test seropositive for antibodies against the bacteria. For example in NE Thailand, $80 \%$ of the population have seroconverted by the age of 4 years (Kanaphun et al., 1993). Yet in spite of constant exposure, only a relatively small fraction of the population develops active disease, mostly if they have underlying risk factors which compromise their immune system, the most prominent of these being diabetes mellitus (Chaowagul et al., 1989; Suputtamongkol et al., 1999; Currie et al., 2000, 2004; Chrispal et al., 2010). A study of individuals with no history of disease from an endemic region of Thailand found a significant correlation between increasing antibody titer and specific IFN $\gamma$ production by $\mathrm{T}$ cells (Tippayawat et al., 2009). Together these factors suggest that those exposed to B. pseudomallei and do not develop disease have acquired some form of protective immunity, and this provides grounding for the theory that vaccination against melioidosis is feasible. In further support of this, is the observation that specific IgG antibodies to $B$. pseudomallei LPS were found to be significantly higher in patients who survived melioidosis compared to those who died from disease, and also in patients with non-septic melioidosis compared to septic patients (Charuchaimontri et al., 1999).

On the other hand, there is data to be considered which imply the development of a vaccine against $B$. pseudomallei may be intrinsically difficult. Whilst in Thailand the seroconversion rate is very high, the percentages of seropositive individuals can vary greatly between regions and subpopulations in other endemic areas (Cheng et al., 2008; Adler et al., 2009). For example in Northern Australia just 5\% of the population are seropositive and there is no correlation between antibody and IFN $\gamma$ production as there is in Thailand (Ashdown and Guard, 1984; Lazzaroni et al., 2008). Furthermore, whilst high levels of specific antibody can be detected in sera from melioidosis patients, it is important to note that recovered melioidosis patients are not protected against further episodes of disease (Kanaphun et al., 1993; Vasu et al., 2003; White, 2003; Maharjan et al., 2005). This implies that an effective vaccine will need to work more efficiently and/or in a different manner than the naturally occurring immune response observed in these individuals. However, whilst development of sterilizing immunity by vaccination is the ultimate goal, even a partially effective vaccine may provide clinical benefit if used in combination with other types of intervention to control disease. We have recently shown that combining prophylactic vaccination plus a generic immunostimulant around the time of exposure decreases the risk of sepsis and delays mortality (Easton et al., 2011). It might also be possible to use vaccines in combination with antibiotics. The risk of death in acute melioidosis is strongly related to the presence or absence of bacteremia upon presentation. Furthermore, $50 \%$ of patient mortality occurs within $48 \mathrm{~h}$ of presentation in a hospital and many individuals die before antibiotic therapy can start. Therefore development of a vaccine which delays the onset of bacteremia and acute disease could extend the window of opportunity for antibiotic treatment and still be of significant clinical benefit.

\section{ANIMAL MODELS OF MELIOIDOSIS FOR VACCINE RESEARCH}

Animal models of infection are an essential component of any vaccine development pipeline and are used for defining immune responses that mediate protection, preclinical testing of potential vaccine candidates and generating immune correlates of protection which can then be applied to Phase I and later studies in humans. B. pseudomallei is not host specific and can infect a broad range of animal species such as cattle, horses, rodents, sheep, pigs, cats, dogs, goats, camels, dolphins, kangaroos, koalas, deer, and water buffalo (Titball et al., 2008). Due to issues of cost, logistics, and availability of immunological reagents, experimental melioidosis has been primarily studied in rodents, and to date three models of infection have been characterized. Syrian hamsters are highly susceptible to $B$. pseudomallei infection with an $\mathrm{LD}_{50}$ (dose required for $50 \%$ mortality) of $<10 \mathrm{CFU}$ via the i.p route (Jones et al., 1997). This is an extremely acute disease model with most deaths occurring within $48 \mathrm{~h}$ post challenge. Another acute model of infection has been developed in diabetic rats. Only infant diabetic rats up to 4 weeks old are susceptible to $B$. pseudomallei, with $\mathrm{LD}_{50}$ doses reported to be $<2 \times 10^{4} \mathrm{CFU}$ via the i.p. route. However, the mouse model of infection with $B$. pseudomallei is the most extensively studied and best characterized, and has proved 
invaluable to our understanding of the immunopathogenesis of melioidosis.

Currently, there is a highly susceptible model established in the $\mathrm{BALB} / \mathrm{c}$ mouse representing acute human melioidosis, and a more resistant $\mathrm{C} 57 \mathrm{BL} / 6$ mouse model which mimics a chronic human infection (Leakey et al., 1998; Liu et al., 2002). In both cases the intranasal (i.n.) or inhalation (aerosol) route is the most susceptible compared to i.p. or subcutaneous (s.c.), with a typical $\mathrm{LD}_{50}$ dose of 5-100 CFU required for acute disease in BALB/c mice (Titball et al., 2008; Lever et al., 2009). C57BL/6 mice consistently show 10 - to 100 -fold greater resistance to $B$. pseudomallei compared to $\mathrm{BALB} / \mathrm{c}$ mice, regardless of the route of infection (Leakey et al., 1998; Hoppe et al., 1999; Liu et al., 2002; Tan et al., 2008; Titball et al., 2008). Infection with $B$. pseudomallei in BALB/c mice is characterized by rapid, highly elevated IFN $\gamma, \mathrm{TNF} \alpha, \mathrm{IL}-1 \beta$, and IL-6 production, accompanied by high bacterial burdens in the spleen, lungs, and liver and development of overwhelming bacteremia within $96 \mathrm{~h}$ of infection (Leakey et al., 1998; Hoppe et al., 1999; Ulett et al., 2000a; Liu et al., 2002). In contrast C57BL/6 mice demonstrate a slower pro-inflammatory cytokine response of lower magnitude with IFN $\gamma$ production persisting throughout the infection (Ulett et al., 2000a,b). These mice have very low organ burdens and no detectable bacteria in the blood at 3 days post infection, though still eventually succumb to infection after 2-6 weeks (Leakey et al., 1998). Thus it has been suggested the control and regulation of IFN $\gamma$ production, and the early downregulation of other pro-inflammatory cytokines allow C57BL/6 mice to balance the protective cell-mediated immune response conferring resistance, with the development of immunopathology (Ulett et al., 2000a,b; Liu et al., 2002). However the precise genetic differences which control resistance to $B$. pseudomallei in these two mouse strains have not been determined.

Patients with melioidosis have elevated serum TNF $\alpha, \mathrm{IL}-1 \beta$, and IL-6 levels, and increasing concentrations of these cytokines correlate with disease severity and the onset of fatal sepsis (Friedland et al., 1992; Suputtamongkol et al., 1992; Wiersinga et al., 2007a). In addition, patients with severe bacteremic melioidosis have very high serum levels of IFN $\gamma$, along with elevated levels of the IFN $\gamma$ inducing cytokines IL-12, IL-18, and IL-15 (Brown et al., 1991; Lauw et al., 1999), this further demonstrates the parallels between human melioidosis and mouse models. High serum levels of IL10 are detected in melioidosis patients, which in conjunction with IL-6 is considered a prognostic indicator of mortality (Simpson et al., 2000; Wiersinga et al., 2007a). Therefore, in some respects, the mouse is a good model of acute melioidosis in humans, and therefore will hopefully predict vaccine efficacy in non-human primates and humans.

Large animal models of experimental melioidosis are rare, yet there are studies which have assessed the susceptibility of various non-human primate species to naturally occurring infection (Trakulsomboon et al., 1994; Sprague and Neubauer, 2004). Many of the symptoms observed during infection in these animals are also prominent in human disease, and the further development of such models may be central to the development of vaccines in the future (Sprague and Neubauer, 2004; Titball et al., 2008).

Finally, recent studies have considered infection models which avoid the use of mammals. Both phagocytic ameba (Dictyostelium discoideum) and wax moth larvae (Galleria mellonella) models have demonstrated the ability to discriminate between different isolates and genetic mutants of $B$. pseudomallei depending on their virulence (Hasselbring et al., 2011; Wand et al., 2011). Although such models cannot be used to directly assess the protective efficacy of defined experimental vaccines, they do provide novel and inexpensive, high-throughput screening systems with which to determine future virulence factors and thus potential vaccine candidates.

\section{CURRENT VACCINE STRATEGIES LIVE ATTENUATED VACCINES}

Live attenuated (LA) vaccines, such as BCG, measles, mumps, and rubella vaccines, induce strong immunity in the host and often only one immunizing dose is required to elicit protective longlasting protective immunity. Since LA vaccines replicate in vivo before being cleared by the host, this type of vaccine can strongly stimulate both the humoral and cell-mediated arms of the immune system, making them some of the most effective vaccines against human pathogens (Pirofski and Casadevall, 1998; Liljeqvist and Ståhl, 1999; Titball, 2008). Yet there are safety concerns about the development of LA vaccines, involving the possibility of reversion to virulent wild-type strains which can cause disease or whether they are safe for immunocompromised patients, a growing population in society today (Pirofski and Casadevall, 1998). For example the measles vaccine is currently not given to children with defects in CMI (with the exception of asymptomatic HIV patients) and there have been several reported cases of disseminated infection following vaccination in the past (Mitus et al., 1962; Monafo et al., 1994; Pirofski and Casadevall, 1998). Reports have also demonstrated similar results following BCG vaccination, and hence this vaccine is not recommended for use in patients with impaired immunity (Pirofski and Casadevall, 1998). For example, with the now acknowledged risks of giving BCG to HIV infected children, new LA TB vaccines will need to show significantly less virulence than BCG in immunocompromised mice before being accepted into Phase I trials.

In the case of $B$. pseudomallei, a number of naturally attenuated or genetically altered bacteria have been tested for protective efficacy, starting with pioneering studies by Dannenberg and Scott (1958a,b, 1960). More recently, Stevens et al. (2004) used an attenuated $B$. pseudomallei bip D mutant, which has a dysfunctional TTSS, to immunize mice. Partial protection was seen in vaccinated mice after challenge with virulent wild-type B. pseudomallei, but immunization with the purified Bip D protein was not protective (Stevens et al., 2004; Druar et al., 2008). An attenuated acapsular mutant of $B$. pseudomallei was considered a potential vaccination candidate, however i.p. immunization did not protect mice against subsequent challenge with virulent B. pseudomallei (Atkins et al., 2002b). B. pseudomallei purN $N^{-}$and purM $^{-}$mutants, which have defects in the purine biosynthesis pathway, important for RNA and DNA synthesis and consequently bacterial replication have also been tested (Pilatz et al., 2006; Breitbach et al., 2008). These were able to protect $\mathrm{BALB} / \mathrm{c}$ mice against acute challenge with virulent B. pseudomallei, however immunization could not prevent the chronic stages of melioidosis (Breitbach et al., 2008). Protection was incomplete and when any surviving mice were examined, 
abscesses were observed and bacteria could be isolated from multiple organs (Breitbach et al., 2008). It should be noted that at present there is no vaccine model which has shown protection against chronic melioidosis.

Atkins et al. (2002a) identified a B. pseudomallei ilvI mutant, termed 2D2. The ilvI gene encodes part of an enzyme required for the biosynthesis of branched chain amino acids (leucine, isoleucine, and valine), and interruption in this gene renders the bacteria auxotrophic for these essential amino acids. Hence, $B$. pseudomallei 2D2 was highly attenuated in mice and effectively cleared from multiple organs after 30 days (Atkins et al., 2002a). Immunization via the i.p. route protected susceptible $B A L B / c$ mice from subsequent challenge with virulent $B$. pseudomallei strain 576, with a significant reduction in bacterial loads in the spleen compared to unvaccinated controls (Atkins et al., 2002a; Haque et al., 2006b). However protection was incomplete and mice eventually succumbed to infection around day 50 post challenge (Haque et al., 2006b). Vaccinated mice were also protected against challenge with the heterologous strain B. pseudomallei BRI, yet protection was specific to $B$. pseudomalle $i$ as when challenged with the facultative intracellular human pathogen $F$. tularensis no protection was seen (Atkins et al., 2002a). In vitro stimulation of splenocytes from 2D2-immunized mice showed increased $\mathrm{T}$ cell proliferation and IFN $\gamma$ production in response to irradiated $B$. pseudomallei 576 and TTSS antigens Bop E and Bip D, compared to controls, indicating 2D2 can efficiently prime T cells (Haque et al., 2006b). Adoptive transfer of T cells from 2D2-immunized mice into severe combined immune deficient (SCID) mice, which have no T or B cells, was able to protect these highly susceptible mice against B. pseudomallei infection (Haque et al., 2006b). The addition of immune sera to $\mathrm{T}$ cell transfer further enhanced the protection, indicating that 2D2 elicits a humoral and cell-mediated immune response (Haque, unpublished observation). Antibody depletion experiments in 2D2-immunized mice demonstrated the importance of $\mathrm{CD}^{+}{ }^{+} \mathrm{T}$ cells, rather than $\mathrm{CD}^{+} \mathrm{T}$ cells, in conferring the protection seen in this mouse model (Haque et al., 2006b).

The concerns over safety of LA vaccines and potential latency associated with this bacterium make it unlikely the B. pseudomallei mutants discussed above will progress further in vaccine development. However there is evidence to suggest LA M. tuberculosis vaccines, such as MTBVAC01 which has disruptions in the associated-virulence regulator gene $p h o P$, will enter clinical trials in the next few years (Verreck et al., 2009; Kaufmann et al., 2010). Thus there may be hope for LA B. pseudomallei vaccine development in the future if additional mutations were introduced which limit the potential of the bacterium to persist in the host. Nonetheless, an alternative and more feasible approach is the development of a vaccine using dead B. pseudomallei, otherwise known as killed whole cell (KWC) vaccines.

\section{KILLED WHOLE CELL VACCINES}

Killed whole cell vaccines cannot replicate and are therefore noninfectious, and this type of vaccine has been licensed for human use against bacteria such as Bacillus anthracis, Vibrio cholerae, Bordetella pertussis, and Yersinia pestis (Pirofski and Casadevall, 1998). However, whilst this type of vaccine is undoubtedly safer compared to live vaccines, the protective immunity induced is weaker, possibly due to lack of CMI responses or the destruction of antigens during the killing process (Ivanoff et al., 1994; Griffin et al., 2007; Titball, 2008). On the other hand, KWC vaccines can induce strong antibody-specific responses which can mediate protection: for example the pertussis vaccines generate neutralizing antibodies against the pertussis toxin and this is a key element in their protective efficacy (Hewlett, 1997). Hence KWC vaccines are generally more protective against extracellular compared to intracellular bacteria.

There are concerns associated with KWC vaccines as well. In most cases protection requires multiple immunization doses, and there are clear risks of reactogenicity and adverse effects in the recipient. This has been observed with the current KWC Y. pestis vaccine, as well as a $B$. pertussis vaccine $(\mathrm{Pw})$ which has now been replaced with a safer but less immunogenic acellular vaccine $(\mathrm{Pa}$; Higgins et al., 2006; Williamson, 2009). Interestingly the route of vaccination can influence the reactogenicity of KWC vaccines. Parenteral immunization with a KWC vaccine against cholera or typhoid induces adverse reactions in the recipient, however if these vaccines are delivered orally they are well tolerated and much less reactogenic (Ivanoff et al., 1994; Hill et al., 2006).

The few studies which have evaluated this type of vaccine regimen against experimental melioidosis demonstrate conflicting results. Following vaccination of BALB/c mice with multiple low doses of heat-killed B. pseudomallei (HkBps) via the s.c. route, significant increases in serum IgG2a and IgG1 were seen compared to control mice, yet only a low level of proliferation was detected following stimulation of splenocytes with antigen (Barnes and Ketheesan, 2007). In accordance with this observation, barely detectable amounts of IFN $\gamma$ were detected via ELISPOT analysis although significantly enhanced levels of IL-10 were observed in $\mathrm{HkBps}$ vaccinated mice compared to controls (Barnes and Ketheesan, 2007). When challenged via the i.v. route with virulent B. pseudomallei, vaccinated mice were not protected compared to control mice, showing similar bacterial loads in the spleen and $100 \%$ mortality before day 5 post challenge (Barnes and Ketheesan, 2007). On the contrary to this data, one of the first melioidosis vaccine studies demonstrated complete protection for 7 days post challenge using $\mathrm{HkBps}$ and partially purified toxic material to vaccinate mice (Razak et al., 1986). Another publication used high doses of HkBps (more consistent with that of other killed vaccines such as plague and typhoid) to vaccinate $B A L B / c$ mice via the i.p. route and demonstrated significant protection against subsequent i.p. challenge with homologous and heterologous virulent B. pseudomallei strains, with $80-100 \%$ of mice alive after 3 weeks post challenge (Sarkar-Tyson et al., 2009). Due to the threat of infection via inhalation in both a natural and biological warfare situation, protection against aerosol challenge was also evaluated. Vaccinated mice were protected against aerosol challenge, as evidenced by a delayed time to death compared to control mice, but the window of protection was greatly reduced compared to i.p. challenge. Therefore the protection was only partial and surviving mice all had heavy bacterial loads detected in the spleen. More recently, Henderson et al. (2011) vaccinated mice i.n. with $\mathrm{HkBps}$ in combination with cationic liposomes complexed with non-coding plasmid DNA (CLDC) as an adjuvant, 
and demonstrated significant protection against pulmonary challenge up to day 40 post challenge. Whilst there was no evaluation of the immune response in vaccinated mice in these publications, these data clearly demonstrate that vaccination with $\mathrm{HkBps}$ can be protective though the route of immunization and challenge can affect the outcome.

Dendritic cells (DCs) play a key role in the generation of adaptive immune responses during infection via antigen-presentation and activation of T cells. Depending on the nature of the microbial stimulus DCs can direct the development of polarized T cell responses to either a Th1 or Th2 phenotype (Janeway et al., 2008). Accordingly these cells have been utilized as a vaccine-delivery vector to generate CMI responses to B. pseudomallei (Healey et al., 2005; Elvin et al., 2006). Healey et al. employed a "prime-boost" vaccination regimen, the concept of which is to prime with an antigen delivered by one method and then boost with the same antigen given via a different vector/adjuvant, and in doing so induce high quality immune responses by different $\mathrm{T}$ cell subsets (Liljeqvist and Ståhl, 1999; Lu, 2009). This has become a common approach for vaccine development against the most challenging diseases such as HIV, malaria, and tuberculosis (Cai et al., 2006; Magalhaes et al., 2008; Lu, 2009; Sander et al., 2009; Kaufmann et al., 2010). In this case, BALB/c mice were primed with purified DCs pulsed with HkBps and then after 28 days, mice were boosted with $\mathrm{HkBps}$ administered with adjuvant. Following vaccination, small but significant increases in antigen-specific IgG antibodies were detected in the serum. However, strong CMI responses were induced as determined by proliferation and IFN $\gamma$ production by splenocytes from immunized mice in response to restimulation with HkBps. Vaccinated mice were protected against challenge with virulent
B. pseudomallei with $60 \%$ survival at day 35 , however bacteria were detected in tissues of surviving mice suggesting that sterilizing immunity was not achieved (Healey et al., 2005). Whilst this vaccination regimen enhanced CMI responses, it induced relatively low antibody production. A further study however, found adding CpG ODN to the DC culture conditions increased antibody production and correlated with a significant increase in survival after challenge (Elvin et al., 2006). This data highlights the need for vaccines to incorporate targets of both humoral and CMI responses.

\section{SUBUNIT VACCINES}

The focus of new vaccine development in recent years has largely been directed toward the use of discrete bacterial components known as subunits. Indeed there are several subunit vaccines available for human use, such as toxoid vaccines (inactivated bacterial toxins) against diphtheria and tetanus, and CPS vaccines against meningococcal or pneumococcal diseases (Pirofski and Casadevall, 1998; Fry et al., 2002). In accordance with this, a number of subunit vaccine candidates have been evaluated for use against $B$. pseudomallei and are summarized in Table 1 . The subunits purified from pathogenic organisms are generally safe to use providing the extraction procedure or detoxifying method can separate them from potentially reactogenic material (Liljeqvist and Ståhl, 1999). However, the production of such vaccines often requires the cultivation of pathogenic organisms on a large scale which can be costly and hazardous (Liljeqvist and Ståhl, 1999). An alternative to this method is the generation of recombinant subunits, in which the gene encoding the subunit is isolated from the host organism and transferred into a different organism which is non-pathogenic,

Table 1 | Subunit vaccine candidates tested to date.

\begin{tabular}{|c|c|c|c|}
\hline Antigen & Composition & Protection & References \\
\hline LPS & Lipopolysaccharide & $80 \%$ Survival at day 14 after 4,300 MLD challenge & Nelson et al. (2004) \\
\hline CPS & Polysaccharide & $40 \%$ Survival at day 14 after 4,300 MLD challenge & Nelson et al. (2004) \\
\hline Flagellin & Naked DNA & $80-90 \%$ Survival at day 14 after up to 100 LD 50 challenge & Chen et al. (2006a,b), Brett et al. (1994) \\
\hline Flagellin & Protein & $50 \%$ Survival at day 7 after up to 100 LD 50 challenge & Chen et al. (2006a), Brett et al. (1994) \\
\hline $\begin{array}{l}\text { Flagellin-O- } \\
\text { antigen } \\
\text { conjugate }\end{array}$ & $\begin{array}{l}\text { Protein- } \\
\text { polysaccharide }\end{array}$ & $\begin{array}{l}\text { Passive transfer of sera protected } 40 \% \text { of diabetic rats } \\
\text { from } 400 L D_{50} \text { challenge at day } 8\end{array}$ & Brett and Woods (1996) \\
\hline ВipB, BipC, BipD & Protein & None at day 5 after 30 LD 50 challenge & Druar et al. (2008) \\
\hline Omp85 & Protein & $70 \%$ Survival at day 15 after $10 \times L_{50}$ challenge & Su et al. (2010) \\
\hline EF-TU & Protein & $\begin{array}{l}\text { Reduced colonization after aerosol challenge with } \\
1 \times L_{50} \text { B. thailandensis }\end{array}$ & Nieves et al. (2010) \\
\hline $\begin{array}{l}\text { BPSL2522 } \\
\text { (Omp3) }\end{array}$ & Protein & $50 \%$ Survival at day 14 after $10 \times L_{50}$ challenge & Hara et al. (2009) \\
\hline $\begin{array}{l}\text { BPSL2765 } \\
\text { (Omp7) }\end{array}$ & Protein & $75 \%$ Survival at day 14 after $10 \times L_{50}$ challenge & Hara et al. (2009) \\
\hline LoIC & Protein & $80 \%$ Survival at day 14 after 153 MLD challenge i.p. & Harland et al. (2007b) \\
\hline
\end{tabular}

The antigens listed were purified from B. pseudomallei (LPS and CPS), or produced as recombinant proteins in E. coli and then purified. The ability of these antigens to induce protective immunity in mice toward an intraperitoneal (i.p.) challenge (aerosol challenge for EF-Tu) with B. pseudomallei (B. thailandensis for EF-Tu) is summarized as the proportion of surviving mice on the day indicated post challenge. Protection studies with the flagellin-O-antigen conjugate were carried out after the passive transfer of sera into diabetic rats which were then challenged with B. pseudomallei. Lethal dose $50 \%$ (LD 50 ) and median lethal dose (MLD) are broadly equivalent. 
such as E. coli. The recombinant subunit is then produced by the heterologous host and can be designed to be delivered as a purified immunogen, or as purified DNA encoding the immunogen (Liljeqvist and Ståhl, 1999).

Purified CPS have been investigated as subunit vaccines and have demonstrated protection against several pathogens, however this approach does have some limitations. CPS are type II antigens, meaning they stimulate antibody production by $\mathrm{B}$ cells independently of MHC Class II-restricted T cell help, hence a predominantly IgM antibody response is induced with suboptimal memory (Pirofski and Casadevall, 1998). In the case of licensed CPS vaccines, booster immunizations are often required to maintain antibody titers (Jones, 2005). Conjugation of CPS to immunogenic proteins (such as tetanus toxoid) overcomes these problems by providing potent $\mathrm{T}$ cell help and has revolutionized the prevention of Haemophilus influenza type B, pneumococcal and meningococcal infections among others (Danzig, 2004; Bernatoniene and Finn, 2005; Eskola, 2010).

Administration of purified LPS has also been explored as a vaccine. In an experimental model of $K$. pneumonia infection, vaccination with purified LPS protected mice against subsequent challenge (Clements et al., 2008). This has also been seen with Brucella melitensis and P. aeruginosa (Preston et al., 1997; Bhattacharjee et al., 2006). However, as with CPS vaccines, lack of CMI induction by LPS vaccines can result in limited protection against intracellular bacteria such as Francisella tularensis (Fulop et al., 2001).

Following the discovery that antibodies to B. pseudomallei LPS were more prominent in patients who survived melioidosis compared to those who died (Charuchaimontri et al., 1999), the use of monoclonal antibodies against LPS and CPS as potential vaccines were evaluated in BALB/c mice (Jones et al., 2002). Following passive immunization via the i.v. route, mice showed a significantly delayed time to death yet still succumbed to infection, demonstrating incomplete protection against the subsequent i.p. challenge with virulent B. pseudomallei (Jones et al., 2002). Another study by Nelson et al. (2004) evaluated these two surface polysaccharides as subunit vaccines and conducted active immunization experiments in BALB/c mice. Mice vaccinated i.p. with LPS developed strong IgM and IgG3 antibody responses, whilst CPS induced a predominately IgG2b antibody response and minimal IgM and IgG3 responses (Nelson et al., 2004). Protection against B. pseudomallei challenge was demonstrated following vaccination with both antigens, however this was only the case against i.p. challenge as when mice were challenged via the aerosol route no protection was observed (Nelson et al., 2004). The addition of adjuvant enhanced the protection seen with CPS but this was not the case with LPS (Nelson et al., 2004). As with passive immunization, the protection afforded by this method was again only partial and mice eventually succumbed to infection (Nelson et al., 2004). A recent study used HkBps mutants which had disruptions in the type I O-PS (capsule), type II O-PS (LPS), type III O-PS, and type IV O-PS surface polysaccharide gene clusters (Sarkar-Tyson et al., 2007). Immunization of BALB/c mice with all four $\mathrm{HkBps}$ mutant strains resulted in delayed time to death compared to naive controls when challenged i.p. with virulent $B$. pseudomallei, however the protection afforded by each strain varied, possibly highlighting the importance of each polysaccharide in protection (Sarkar-Tyson et al., 2007).

The related bacterium $B$. thailandensis which is considered to be avirulent in humans can often be isolated from soil in endemic areas of Thailand (Smith et al., 1997). Studies have shown the LPS structure of this organism to be similar to that of B. pseudomallei, yet it elicits stronger immune responses from human and murine macrophage cell lines in vitro compared to its virulent counterpart (Anuntagool et al., 1998; Brett et al., 2003; Qazi et al., 2008; Novem et al., 2009; Ngugi et al., 2010). Recently LPS isolated from B. thailandensis was evaluated as a potential vaccine candidate. Immunized mice were protected from subsequent challenge with B. pseudomallei with $50 \%$ survival at day 35 , however bacteria could be detected in the tissues of these surviving mice suggesting sterilizing immunity was not achieved and the infection would ultimately prove fatal (Ngugi et al., 2010). The use of B. thailandensis as a vaccine against melioidosis has not been widely explored to date but there are reports of live and heat-killed $B$. thailandensis also providing protection against $B$. pseudomallei infection (Iliukhin et al., 2002; Sarkar-Tyson et al., 2009). Considering the financial and safety benefits of working with a Containment Level 2 organism this is an area of melioidosis vaccine research which should continue to be explored.

Antibodies against other known B. pseudomallei virulence factors such as flagella have also been investigated as vaccine candidates. Anti-flagellin antibodies are known to reduce bacterial motility and have shown some passive protection against infection in diabetic rats (Brett et al., 1994). A subsequent publication by the same authors attempted to enhance the immunological repertoire of the vaccine recipient by conjugating flagellin proteins to the O-PS moiety of LPS isolated from the same strain, thereby developing the first conjugate vaccine for this infection (Brett and Woods, 1996). Passive immunization with the flagellinpolysaccharide conjugate still only provided partial protection in diabetic rats (Brett and Woods, 1996). To date conjugate vaccines against $B$. pseudomallei using better defined protein carriers such as those found in pneumococcal vaccines have not been reported.

The limited success of these vaccine studies, which universally resulted in only partial protection, is thought to be due to the lack of $\mathrm{T}$ cell stimulation afforded by these strategies. Thus, some attempts to resolve these problems have involved the evaluation of DNA vaccines. These consist of small circular bacterial DNA (plasmid) expression vectors, which encode candidate vaccine antigens under the control of strong viral promoters which are recognized by the host (Liljeqvist and Ståhl, 1999). Following plasmid DNA vaccination, the antigen is expressed by the host cells and delivered to antigen-presenting cells, resulting in strong T CMI (Plotkin, 2009). A significant potential advantage of DNA vaccines is the ability to induce $\mathrm{CD}^{+} \mathrm{T}$ cell responses via MHC class I presentation, which is important for protection against other intracellular pathogens (Kaufmann et al., 2010). Parenteral vaccinations via injection or gene gun delivery are the most common modes of DNA vaccine delivery. However this is less advantageous in targeting the mucosal surfaces. Furthermore, whilst DNA vaccines have achieved success in most animal models, only modest immunogenicity has been observed in higher primates and human clinical trials posing an ongoing challenge of formulating DNA vaccines 
for use in humans (Coban et al., 2008). In attempts to improve the efficacy of DNA vaccines the genetic manipulation of live vectors, primarily bacteria or viruses, expressing pathogen-specific DNA has also been investigated. A prime example of this technique can be seen in $M$. tuberculosis vaccines, where a number of candidates have been generated using recombinant, replication-deficient vaccinia virus or adenoviruses which express the mycobacterial Ag85A (termed MVA85A and AdAg85A respectively; McShane et al., 2004; Santosuosso et al., 2006; Radosevic et al., 2007; Sander et al., 2009). These can induce strong Th1 immunity, including CD8 ${ }^{+}$ $\mathrm{T}$ cell responses, and are being evaluated in clinical trials for further development (Kaufmann et al., 2010). A limitation of these vaccines however, is reduced efficacy following previous exposure to the vector, such as previous vaccination with vaccinia or natural exposure to cross-reacting strains of adenovirus (reviewed in Bangari and Mittal, 2006).

DNA vaccines have also been investigated to a limited degree in melioidosis. Chen et al. evaluated a DNA vaccine encoding the fliC gene and demonstrated protection against $B$. pseudomallei infection in $\mathrm{BALB} / \mathrm{c}$ mice. Intramuscular (i.m.) vaccination with this construct elicited both humoral and cell-mediated immune responses, demonstrated by increased IgG production and enhanced proliferation of splenocytes in response to $B$. pseudomallei flagellin (Chen et al., 2006b). IgG2a was the dominant antibody subclass detected, and a higher number of IFN $\gamma$ secreting cells were found in the spleens of immunized mice, indicating the induction of a Th1 phenotype (Chen et al., 2006b). Immunized mice showed better control of bacterial burden in organs and increased survival after i.v. challenge compared to controls (Chen et al., 2006b). Addition of the immunoadjuvant, cytosine preceding a guanosine motif oligodeoxynucleotide (CpG ODN), to the plasmid DNA encoding flagellin further enhanced the protective effects elicited by this vaccination strategy (Chen et al., 2006a).

Purified proteins have had some success as potential vaccine candidates against other bioterrorism agents. For example, $Y$. pestis secretes a number of virulence factors which include Fraction 1 (F1) and V (virulence) proteins. These have been formulated together in recombinant subunit vaccines, and can induce protective immunity against plague (Williamson, 2009). However the use of single proteins or peptides as vaccines has had limited success due to restricted immunogenicity within the host, and often must be delivered with adjuvants to elicit protection. Furthermore, this approach requires the identification of virulence determinants or immunogenic epitopes as potential vaccine candidates, which in the case of intracellular bacteria can prove challenging (Titball, 2008). Nonetheless, in an attempt to identify novel vaccine antigens for B. pseudomallei, Harland et al. (2007b) evaluated proteins of the ABC systems. ABC systems are widespread among living organisms and are thought to have roles in nutrient uptake and survival, as well as drug resistance and virulence (Garmory and Titball, 2004). Comprising one of the largest protein families in prokaryotes, ABC systems are characterized by a highly conserved ATPase domain which binds ATP and provides energy for the conserved $\mathrm{ABC}$ proteins to import and export a wide variety of substrates across the membrane (Garmory and Titball, 2004). Given the location of the ABC transporters it is possible that some protein components of the system are exposed to the immune system during infection, making them attractive as potential vaccine candidates. Three $B$. pseudomallei ABC transporter proteins, namely LolC, PotF, and OppA, were selected as candidate vaccine antigens following annotation of the reference strain B. pseudomallei K96423 (Harland et al., $2007 a, b)$. Immunization of BALB/c mice with each protein mixed with adjuvant generated protein-specific IgG responses which were biased toward the IgG2a isotype and therefore a Th1 phenotype (Harland et al., 2007b). In addition, restimulation assays using $\mathrm{T}$ cells from spleens of immunized mice, detected proteinspecific IFN $\gamma$ production in culture supernatants (Harland et al., 2007b).

This work indicated that all three proteins were capable of inducing both antigen-specific humoral and CMI responses. When mice were challenged i.p. with virulent $B$. pseudomallei K96423, PotF, and LolC vaccinated mice were significantly protected compared to naive mice, whilst vaccination with OppA showed no protection (Harland et al., 2007b). LolC was the most protective protein and when combined with immune stimulating complexes (ISCOMS) adjuvant in a complex with CpG ODN, the protection afforded by this vaccine was enhanced (Harland et al., 2007b). Mice immunized with LolC were also significantly protected against challenge with the heterologous strain B. pseudomallei 576 (Harland et al., 2007b). However despite the relative success of this candidate vaccine, protection against melioidosis was still incomplete as mice eventually succumbed to infection.

A recent study highlighted the $B$. pseudomallei outer membrane protein A family (OmpA) as being immunogenic in mice as well as melioidosis patients (Hara et al., 2009). Evaluation of the B. pseudomallei whole genome sequence identified $12 \mathrm{OmpA}$ domains. Following annotation of the relevant open reading frames (ORFs) two of these OmpAs, namely Omp3 and Omp7, were successfully expressed as soluble protein and subsequently purified. Immunization of $\mathrm{BALB} / \mathrm{c}$ mice with either Omp3 or Omp7 administered with adjuvant, significantly enhanced survival time following subsequent challenge with $B$. pseudomallei. Another study considered the Omp85 protein family as potential vaccine candidates (Su et al., 2010). As with the OmpAs, $\mathrm{BALB} / \mathrm{c}$ mice immunized with recombinant Omp85 demonstrated increased survival as well as reduced bacterial burdens in tissues compared to unvaccinated controls (Su et al., 2010). Thus pilot experiments with Omp family proteins have demonstrated protective efficacy in animal models of melioidosis and studies with these proteins continue (Hara et al., 2009; Su et al., 2010). However it should be noted that the protection afforded was no greater than that observed previously with other strategies. Another abundant protein family which could be considered for vaccine research are the autotransporter proteins. These outer membrane/secreted proteins facilitate transport across the bacterial cell membrane and to the cell surface, and have been implicated in virulence of some Gram-negative bacteria (Henderson et al., 2004; Wells et al., 2007). Investigation of this system in B. pseudomallei could provide more candidate proteins for vaccine development against melioidosis. Thus, the search for novel vaccine antigens against $B$. pseudomallei is continuing. 
In summary it is clear that a number of different strategies are under investigation for the development of new vaccines against melioidosis. However better understanding of specific pathogenhost interactions in vivo, as well as identification of key virulence determinants and correlates of protection, are needed to enhance vaccine research and development in the future.

\section{DISCUSSION}

A subunit vaccine based on a combination of protein and polysaccharide seems the most promising candidate melioidosis vaccine. Although there are some studies from the 1990s which demonstrate the feasibility of such a vaccine, there is no material currently available for testing, and no robust and reliable process for producing such a vaccine. The further development of a vaccine is also likely to depend on the nature of the population to be protected. For example, in South East (SE) Asia most of the individuals who develop melioidosis have an underlying condition that increases their susceptibility to disease. Thus individuals are effectively imunosuppressed, meaning that vaccines may be less effective in this group. The current assumption is that many of these individuals contract the disease via cuts and abrasions but it is possible that some cases are the consequence of the ingestion or inhalation of bacteria. In contrast a biodefense vaccine would need to protect the general population against an airborne challenge and would need to protect healthy individuals in addition to those with an underlying condition which pre-disposes them to disease. Ideally, a vaccine would be able to protect both of these groups and this linkage has several clear potential benefits. Firstly, it seems unlikely that a melioidosis vaccine for use in endemic areas in SE Asia would be economically viable without the ability to also use this vaccine for biodefense purposes. Secondly, the ability to identify at-risk groups in Thailand, or indeed other parts of SE Asia, would allow meaningful clinical trials to be carried out.

There is still considerable debate over the most appropriate animal model for testing vaccine candidates. Many of the studies carried out to date are in highly susceptible BALB/c mice and this model is more suitable to the study of acute melioidosis. In contrast C57BL/6 mice develop either acute or chronic disease depending on the challenge dose. The characteristic clinical features of human melioidosis such as acute versus chronic disease, pneumonia, and abscess formation in the liver and spleen are therefore mirrored in the C57BL/6 model. In studies we have carried out, the degree of protection offered by various immunogens has been greater in $\mathrm{C} 57 \mathrm{BL} / 6$ than in $\mathrm{BALB} / \mathrm{c}$ mice. Whilst a large proportion of an endemic population is exposed to $B$. pseudomallei only relatively few develop clinical disease, suggesting the majority of people have some form of resistance against melioidosis. Alternatively given the risk factors associated with melioidosis, the organism may only be capable of causing disease in an immunocompromised host. Nonetheless the immune responses elicited by patients who develop clinical infection are likely to be different to those who remain asymptomatic, so identifying immune responses under conditions of the strongest vaccine protection in resistant mice may provide insights into what is required from future vaccine designs. Our laboratories have addressed this problem and preliminary data demonstrated that following i.n. vaccination with 2D2,
C57BL/6 mice were significantly protected against i.n. challenge with B. pseudomallei 576 with $60 \%$ of mice still alive 250 days post challenge (A. Easton, unpublished data). To determine if the surviving mice had completely cleared the infection, they were treated with dexamethasone which suppresses the immune system and consequently reactivation of acute infection can occur due to the presence of persistent bacteria. However all mice survived the dexamethasone treatment and no bacteria were detected in the spleen, lung, or liver indicating that these mice had in fact achieved sterilizing immunity following 2D2 vaccination (A. Easton, unpublished data). This vaccine strategy thus provides the best protection against experimental melioidosis to date, and further investigation using the resistant C57BL/6 model in vaccination studies is ongoing.

Whilst the i.p. route is commonly used in experimental animal models, the s.c. or i.n. route of infection could be considered more physiologically relevant model for melioidosis. In human B. pseudomallei infection, inhalation is an important route of exposure in both endemic regions and in a potential bioterrorism situation. Involvement of the lung is often associated with severe disease with pneumonia being the most prominent clinical presentation of melioidosis in all studies (Howe et al., 1971; Guard et al., 1984; Chaowagul et al., 1989; Puthucheary et al., 1992; Simpson et al., 1999; Currie et al., 2000; Chrispal et al., 2010). Despite the importance of pulmonary B. pseudomallei infection, very few studies have investigated vaccine-mediated protection against respiratory challenge. Studies of other respiratory infections such as influenza, tuberculosis, and tularemia, have demonstrated that to effectively generate protective mucosal immune responses, the vaccine should be delivered directly to the target mucosa rather than systemically (Hornick and Eigelsbach, 1966; Conlan et al., 2005; Santosuosso et al., 2006; Perrone et al., 2009). Consequently our laboratory has developed an i.n. model of vaccination in BALB/c mice using the B. pseudomallei mutant 2D2. Vaccinated mice were protected against subsequent i.n. challenge, as determined by enhanced survival and reduced bacterial burdens in the spleen and lung (Easton et al., 2011). Of note is the observation that protection against pulmonary B. pseudomallei challenge was significantly greater following i.n. vaccination as opposed to i.p. vaccination (Easton et al., 2011). This phenomenon was also seen in experiments by Breitbach et al. (2008) in which vaccination with attenuated $B$. pseudomallei purine mutants was most effective against pulmonary challenge when administered via the i.n. route. Furthermore a recent study demonstrated i.n. vaccination with $\mathrm{HkBps}$ administered with a potent mucosal adjuvant, was significantly more protective against i.n. challenge compared to HkBps alone (Henderson et al., 2011). Together these data highlight the need to consider the efficacy of pulmonary vaccination and mucosal targeting in the future of melioidosis vaccine design and development.

Finally, since it may be possible to carry our clinical trials with a candidate melioidosis vaccine, there may be a less urgent need for non-human primate models of disease than is the case for other infections caused by bioterrorism agents. Nevertheless, it would be highly desirable to have also tested such a candidate in a suitable non-human primate model. To our knowledge, marmoset, 
rhesus macaque, and African Green monkey models of melioidosis are currently being evaluated and we await the results of these studies.

\section{REFERENCES}

Adler, N. R., Govan, B., Cullinane, M., Harper, M., Adler, B., and Boyce, J. D. (2009). The molecular and cellular basis of pathogenesis in melioidosis: how does Burkholderia pseudomallei cause disease? FEMS Microbiol. Rev. 33, 1079-1099.

Akira, S., Uematsu, S., and Takeuchi, O. (2006). Pathogen recognition and innate immunity. Cell 124, 783-801.

Anuntagool, N., Intachote, P., Wuthiekanun, V., White, N. J., and Sirisinha, S. (1998). Lipopolysaccharide from nonvirulent Ara+Burkholderia pseudomallei isolates is immunologically indistinguishable from lipopolysaccharide from virulent Ara- clinical isolates. Clin. Diagn. Lab. Immunol. 5, 225-229.

Ashdown, L. R., and Guard, R. W. (1984). The prevalence of human melioidosis in Northern Queensland. Am. J. Trop. Med. Hyg. 33, 474-478.

Atkins, T., Prior, R. G., Mack, K., Russell, P., Nelson, M., Oyston, P., Dougan, G., and Titball, R. W. (2002a). A mutant of Burkholderia pseudomallei, auxotrophic in the branched chain amino acid biosynthetic pathway, is attenuated and protective in a murine model of melioidosis. Infect. Immun. 70, 5290-5294.

Atkins, T., Prior, R., Mack, K., Russell, P., Nelson, M., Prior, J., Ellis, J., Oyston, P. C. F., Dougan, G., and Titball, R. W. (2002b). Characterisation of an acapsular mutant of Burkholderia pseudomallei identified by signature tagged mutagenesis. J. Med. Microbiol. 51, 539-553.

Bangari, D. S., and Mittal, S. K. (2006). Development of nonhuman adenoviruses as vaccine vectors. Vaccine 24, 849-862.

Barnes, J. L., and Ketheesan, N. (2007). Development of protective immunity in a murine model of melioidosis is influenced by the source of Burkholderia pseudomallei antigens. Immunol. Cell Biol. 85, 551-557.

Barnes, J. L., Ulett, G. C., Ketheesan, N., Clair, T., Summers, P. M., and Hirst, R. G. (2001). Induction of multiple chemokine and colonystimulating factor genes in experimental Burkholderia pseudomallei infection. Immunol. Cell Biol. 79, 490-501.

Barnes, J. L., Warner, J., Melrose, W., Durrheim, D., Speare, R.,
Reeder, J. C., and Ketheesan, N. (2004). Adaptive immunity in melioidosis: a possible role for $\mathrm{T}$ cells in determining outcome of infection with Burkholderia pseudomallei. Clin. Immunol. 113, 22-28.

Bernatoniene, J., and Finn, A. (2005). Advances in pneumococcal vaccines: advantages for infants and children. Drugs 65, 229-255.

Bhattacharjee, A. K., Izadjoo, M. J., Zollinger, W. D., Nikolich, M. P., and Hoover, D. L. (2006). Comparison of protective efficacy of subcutaneous versus intranasal immunization of mice with a Brucella melitensis lipopolysaccharide subunit vaccine. Infect. Immun. 74, 5820-5825.

Breitbach, K., Klocke, S., Tschernig, T., van Rooijen, N., Baumann, U., and Steinmetz, I. (2006). Role of inducible nitric oxide synthase and $\mathrm{NADPH}$ oxidase in early control of Burkholderia pseudomallei infection in mice. Infect. Immun. 74, 6300-6309.

Breitbach, K., Köhler, J., and Steinmetz, I. (2008). Induction of protective immunity against Burkholderia pseudomallei using attenuated mutants with defects in the intracellular life cycle. Trans. R. Soc. Trop. Med. Hyg. 102, S89-S94.

Breitbach, K., Wongprompitak, P., and Steinmetz, I. (2011). Distinct roles for nitric oxide in resistant C57BL/6 and susceptible $\mathrm{BALB} / \mathrm{c}$ mice to control Burkholderia pseudomallei infection. BMCImmunol. 12, 20. doi: 10.1186/1471-2172-12-20

Brett, P., and Woods, D. E. (1996). Structural and immunological characterization of Burkholderia pseudomallei O-polysaccaride-flagellin protein conjugates. Infect. Immun 64, 2824-2828.

Brett, P. J., Burtnick, M. N., and Woods, D. E. (2003). The wbiA locus is required for the 2-Oacetylation of lipopolysaccharide expressed by Burkholderia pseudomallei and Burkholderia thailandensis. FEMS Microbiol. Lett. 218, 323-328.

Brett, P. J., Mah, D. C., and Woods, D. E. (1994). Isolation and characterization of Pseudomonas pseudomallei flagellin proteins. Infect. Immun. 62, 1914-1919.

Brown, A. E., Dance, D. A., Suputtamongkol, Y., Chaowagul, W.,

\section{ACKNOWLEDGMENTS}

Work in the authors laboratory was supported by National Institute of Health Grant U01AI061363.

Kongchareon, S., Webster, H. K., and White, N. J. (1991). Immune cell activation in melioidosis: increased serum levels of interferon-gamma and soluble interleukin-2 receptors without change in soluble CD8 protein. J. Infect. Dis. 163, 1145-1148.

Cai, H., Yu, D. H., Hu, X. D., Li, S. X., and Zhu, Y. X. (2006). A combined DNA vaccine-prime, BCG-boost strategy results in better protection against Mycobacterium bovis challenge. DNA Cell Biol. 25, 438-447.

Chanchamroen, S., Kewcharoenwong, C., Susaengrat, W., Ato, M., and Lertmemongkolchai, G. (2009). Human polymorphonuclear neutrophil responses to Burkholderia pseudomallei in healthy and diabetic subjects. Infect. Immun. 77, 456-463.

Chaowagul, W., Suputtamongkol, Y., Dance, D. A., Rajchanuvong, A., Pattara-arechachai, J., and White, N. J. (1993). Relapse in melioidosis: incidence and risk factors. J. Infect. Dis. 168, 1181-1185.

Chaowagul, W., White, N. J., Dance, D. A., Wattanagoon, Y., Naigowit, P., Davis, T. M., Looareesuwan, S., and Pitakwatchara, N. (1989). Melioidosis: a major cause of communityacquired septicemia in northeastern Thailand. J. Infect. Dis. 159, 890-899.

Charuchaimontri, C., Suputtamongkol, Y., Nilakul, C., Chaowagul, W., Chetchotisakd, P., Lertpatanasuwun, N., Intaranongpai, S., Brett, P. J., and Woods, D. E. (1999). Antilipopolysaccharide II: an antibody protective against fatal melioidosis. Clin. Infect. Dis. 29, 813-818.

Chen, Y.-S., Hsiao, Y.-S., Lin, H.-H., Liu, Y., and Chen, Y.-L. (2006a). CpGmodified plasmid DNA encoding flagellin improves immunogenicity and provides protection against Burkholderia pseudomallei infection in $\mathrm{BALB} / \mathrm{c}$ mice. Infect. Immun. 74 , 1699-1705.

Chen, Y.-S., Hsiao, Y.-S., Lin, H.-H., Yen, C.-M., Chen, S.-C., and Chen, Y.-L. (2006b). Immunogenicity and antiBurkholderia pseudomallei activity in Balb/c mice immunized with plasmid DNA encoding flagellin. Vaccine 24, 750-758.

Cheng, A., and Currie, B. (2005) Melioidosis: epidemiology, pathophysiology, and management. Clin. Microbiol. Rev. 18, 383-416.

Cheng, A. C., Wuthiekanun, V., Limmathurotsakul, D., Chierakul, W., and Peacock, S. J. (2008). Intensity of exposure and incidence of melioidosis in Thai children. Trans. R. Soc. Trop. Med. Hyg. 102, S37-S39.

Chierakul, W., Wuthiekanun, V., Chaowagul, W., Amornchai, P., Cheng, A. C., White, N. J., Day, N. P. J., and Peacock, S. J. (2005). Disease severity and outcome of melioidosis in HIV coinfected individuals. Am. J. Trop. Med. Hyg. 73, 1165-1166.

Chrispal, A., Rajan, S. J., and Sathyendra, S. (2010). The clinical profile and predictors of mortality in patients with melioidosis in South India. Trop. Doct. 40, 36-38.

Clements, A., Jenney, A. W., Farn, J. L., Brown, L. E., Deliyannis, G., Hartland, E. L., Pearse, M. J., Maloney, M. B., Wesselingh, S. L., Wijburg, O. L., and Strugnell, R. A. (2008). Targeting subcapsular antigens for prevention of Klebsiella pneumoniae infections. Vaccine 26 5649-5653.

Coban, C., Koyama, S., Takeshita, F., Akira, S., and Ishii, K. J. (2008). Molecular and cellular mechanisms of DNA vaccines. Hum. Vaccin. 4, 453-457.

Coffman, R. L., and Carty, J. (1986). A T cell activity that enhances polyclonal IgE production and its inhibition by interferon-gamma. J. Immunol. 136, 949-954.

Conlan, J. W., Shen, H., KuoLee, R., Zhao, X., and Chen, W. (2005). Aerosol-, but not intradermalimmunization with the live vaccine strain of Francisella tularensis protects mice against subsequent aerosol challenge with a highly virulent type A strain of the pathogen by an $\alpha \beta$ T cell- and interferon gammadependent mechanism. Vaccine 23 , 2477-2485.

Currie, B. (2003). Melioidosis: an important cause of pneumonia in residents of and travellers returned from endemic regions. Eur. Respir. J. $22,542-550$.

Currie, B. J. (2008). Advances and remaining uncertainties in the epidemiology of Burkholderia pseudomallei and melioidosis. Trans. R. Soc. Trop. Med. Hyg. 102, 225-227. 
Currie, B. J., Fisher, D. A., Howard, D. M., Burrow, J. N., Lo, D., SelvaNayagam, S., Anstey, N. M., Huffam, S. E., Snelling, P. L., Marks, P. J., Stephens, D. P., Lum, G. D., Jacups, S. P., and Krause, V. L. (2000). Endemic melioidosis in tropical northern Australia: a 10year prospective study and review of the literature. Clin. Infect. Dis. 31, 981-986.

Currie, B. J., and Jacups, S. P. (2003). Intensity of rainfall and severity of melioidosis, Australia. Emerg. Infect. Dis. 9, 1538-1542.

Currie, B. J., Jacups, S. P., Cheng, A. C., Fisher, D. A., Anstey, N. M., Huffam, S. E., and Krause, V. L. (2004). Melioidosis epidemiology and risk factors from a prospective wholepopulation study in northern Australia. Trop. Med. Int. Health 9, 1167-1174.

Dance, D. A. B., Wuthiekanun, V., Chaowagul, W., and White, N. J. (1989). The antimicrobial susceptibility of Pseudomonas pseudomallei. Emergence of resistance in vitro and during treatment. J. Antimicrob. Chemother. 24, 295-309.

Dannenberg, A. M. Jr., and Scott, E. M. (1958a). Melioidosis: pathogenesis and immunity in mice and hamsters. I. Studies with virulent strains of Malleomyces pseudomallei. J. Exp. Med. 107, 153-166.

Dannenberg, A. M. Jr., and Scott, E. M. (1958b). Melioidosis: pathogenesis and immunity in mice and hamsters. II. Studies with avirulent strains of Malleomyces pseudomallei. Am. J. Pathol. 34, 1099-1121.

Dannenberg, A. M. Jr., and Scott, E. M. (1960). Melioidosis: pathogenesis and immunity in mice and hamsters: III. Effect of vaccination with avirulent strains of Pseudomonas pseudomallei on the resistance to the establishment and the resistance to the progress of respiratory melioidosis caused by virulent strains; all-or-none aspects of this disease. J. Immunol. 84, 233-246.

Danzig, L. (2004). Meningococcal vaccines. Pediatr. Infect. Dis. J. 23, S285-S292.

Dennis, D. T., Inglesby, T. V., Henderson, D. A., Bartlett, J. G., Ascher, M. S., Eitzen, E., Fine, A. D., Friedlander, A. M., Hauer, J., Layton, M.,Lillibridge, S. R., McDade, J. E., Osterholm, M. T., O’Toole, T., Parker, G., Perl, T. M., Russell, P. K., Tonat, K., and for the Working Group in Civilian Biodefense. (2001). Tularemia as a biological weapon: medical and public health management. JAMA 285, 2763-2773.
Dorman, S. E., Gill, V. J., Gallin, J. I., and Holland, S. M. (1998). Burkholderia pseudomallei infection in a Puerto Rican patient with chronic granulomatous disease: case report and review of occurrences in the Americas. Clin. Infect. Dis. 26, 889-894.

Druar, C., Yu, F., Barnes, J. L., Okinaka, R. T., Chantratita, N., Beg, S., Stratilo, C. W., Olive, A. J., Soltes, G., Russell, M. L., Limmathurotsakul, D., Norton, R. E., Ni, S. X., Picking, W. D., Jackson, P. T., Stewart, D. I. H., Tsvetnitsky, V., Picking, W. L., Cherwonogrodzky, J. W., Ketheesan, N., Peacock, S. J., and Wiersma, E. J. (2008). Evaluating Burkholderia pseudomallei Bip proteins as vaccines and Bip antibodies as detection agents. FEMS Immunol. Med. Microbiol. 52, 78-87.

Dworkin, M. S., Ward, J. W., Hanson, D. L., Jones, J. L., and Kaplan, J. E. (2001). Pneumococcal disease among human immunodeficiency virus-infected persons: incidence, risk factors, and impact of vaccination. Clin. Infect. Dis. 32, 794-800.

Easton, A., Haque, A., Chu, K., Lukaszewski, R., and Bancroft, G. J. (2007). A critical role for neutrophils in resistance to experimental infection with Burkholderia pseudomallei. J. Infect. Dis. 195, 99-107.

Easton, A., Haque, A., Chu, K., Patel, N., Lukaszewski, R., Krieg, A. M., Titball, R. W., and Bancroft, G. J. (2011). Combining vaccination and postexposure CpG therapy provides optimal protection against lethal sepsis in a biodefense model of human melioidosis. J. Infect. Dis. 204, 636644.

Edelson, B. T., and Unanue, E. R. (2000). Immunity to Listeria infection. Curr. Opin. Immunol. 12, 425-431.

Egan, A. M., and Gordon, D. L. (1996). Burkholderia pseudomallei activates complement and is ingested but not killed by polymorphonuclear leukocytes. Infect. Immun. 64, 4952-4959.

Ekchariyawat, P., Pudla, S., Limposuwan, K., Arjcharoen, S., Sirisinha, S., and Utaisincharoen, P. (2005). Burkholderia pseudomallei-induced expression of suppressor of cytokine signaling 3 and cytokine-inducible Src homology 2-containing protein in mouse macrophages: a possible mechanism for suppression of the response to gamma interferon stimulation. Infect. Immun. 73, 7332-7339.

Elvin, S., Healey, G., Westwood, A., Knight, S., Eyles, J., and Williamson, E. (2006). Protection against heterologous Burkholderia pseudomallei strains by dendritic cell immunization. Infect. Immun. 74, 1706-1711.

Eskola, J. (2010). Foresight in medicine: current challenges with Haemophilus influenzae type b conjugate vaccines. J. Intern. Med. $267,241-250$.

Flynn, J., and Chan, J. (2001). Immunology of tuberculosis. Annu. Rev. Immunol. 19, 93-129.

Friedland, J. S., Suputtamongkol, Y., Remick, D. G., Chaowagul, W., Strieter, R. M., Kunkel, S. L., White, N. J., and Griffin, G. E. (1992). Prolonged elevation of interleukin-8 and interleukin- 6 concentrations in plasma and of leukocyte interleukin8 mRNA levels during septicemic and localized Pseudomonas pseudomallei infection. Infect. Immun. 60, 2402-2408.

Fry, A. M., Zell, E. R., Schuchat, A., Butler, J. C., and Whitney, C. G. (2002). Comparing potential benefits of new pneumococcal vaccines with the current polysaccharide vaccine in the elderly. Vaccine 21, 303-311.

Fulop, M., Mastroeni, P., Green, M., and Titball, R. W. (2001). Role of antibody to lipopolysaccharide in protection against low- and high-virulence strains of Francisella tularensis. Vaccine 19, 4465-4472.

Garmory, H. S., and Titball, R. W. (2004). ATP-binding cassette transporters are targets for the development of antibacterial vaccines and therapies. Infect. Immun. 72 , 6757-6763.

Gilks, C. F., Ojoo, S. A., Ojoo, J. C., Brindle, R. J., Paul, J., Batchelor, B. I., Kimari, J. N., Newnham, R., Bwayo, J., Plummer, F. A., and Warrell, D. A. (1996). Invasive pneumococcal disease in a cohort of predominantly HIV-1 infected female sexworkers in Nairobi, Kenya. Lancet $347,718-723$.

Govan, B., and Ketheesan, N. (2004) Exposure to Burkholderia pseudomallei induces cell-mediated immunity in healthy individuals. Clin. Microbiol. Infect. 10, 585-587.

Griffin, K. F., Oyston, P. C., and Titball, R. W. (2007). Francisella tularensis vaccines. FEMS Immunol. Med. Microbiol. 49, 315-323.

Guard, R. W., Khafagi, F. A., Brigden, M. C., and Ashdown, L. R. (1984). Melioidosis in far north Queensland: a clinical and epidemiological review of twenty cases. Am. J. Trop. Med. Hyg. 33, 467-473.

Haque, A., Easton, A., Smith, D., O'Garra, A., Van Rooijen, N., Lertmemongkolchai, G., Titball, R. W., and Bancroft, G. J. (2006a). Role of
$\mathrm{T}$ cells in innate and adaptive immunity against murine Burkholderia pseudomallei infection. J. Infect. Dis. 193, 370-379.

Haque, A., Chu, K., Easton, A., Stevens, M. P., Galyov, E. E., Atkins, T., Titball, R., and Bancroft, G. J. (2006b). A live experimental vaccine against Burkholderia pseudomallei elicits CD4+ cell-mediated immunity, priming $\mathrm{T}$ cells specific for 2 type III secretion system proteins. J. Infect. Dis. 194, 1241-1248.

Hara, Y., Mohamed, R., and Nathan, S. (2009). Immunogenic Burkholderia pseudomallei outer membrane proteins as potential candidate vaccine targets. PLOS ONE 4, e6496. doi: 10.1371/journal.pone.0006496

Harland, D., Dassa, E., Titball, R., Brown, K., and Atkins, H. (2007a). ATP-binding cassette systems in Burkholderia pseudomallei and Burkholderia mallei. BMC Genomics 8, 83. doi: 10.1186/1471-21648-83

Harland, D. N., Chu, K., Haque, A., Nelson, M., Walker, N. J., SarkarTyson, M., Atkins, T. P., Moore, B., Brown, K. A., Bancroft, G., Titball, R. W., and Atkins, H. S. (2007b). Identification of a LolC homologue in Burkholderia pseudomallei, a novel protective antigen for melioidosis. Infect. Immun. 75, 4173-4178.

Hasselbring, B. M., Patel, M. K., and Schell, M. A. (2011). Dictyostelium discoideum as a model system for identification of Burkholderia pseudomallei virulence factors. Infect. Immun. 79, 2079-2088.

Healey, G. D., Elvin, S. J., Morton, M., and Williamson, E. D. (2005). Humoral and cell-mediated adaptive immune responses are required for protection against Burkholderia pseudomallei challenge and bacterial clearance postinfection. Infect. Immun. 73, 5945-5951.

Henderson, A., Propst, K., Kedl, R., and Dow, S. (2011). Mucosal immunization with liposome-nucleic acid adjuvants generates effective humoral and cellular immunity. Vaccine 29, 5304-5312.

Henderson, I. R., Navarro-Garcia, F., Desvaux, M., Fernandez, R. C., and Ala'Aldeen, D. (2004). Type $\mathrm{V}$ protein secretion pathway: the autotransporter story. Microbiol. Mol. Biol. Rev. 68, 692-744.

Hewlett, E. L. (1997). Preparation and composition of acellular pertussis vaccines. Consideration of potential effects on vaccine efficacy. Dev. Biol. Stand. 89, 143-151. 
Higgins, S. C., Jarnicki, A. G., Lavelle, E. C., and Mills, K. H. G. (2006). TLR4 mediates vaccine-induced protective cellular immunity to Bordetella pertussis: role of IL-17-producing $\mathrm{T}$ cells. J. Immunol. 177, 7980-7989.

Hii, C. S., Sun, G. W., Goh, J. W. K., Lu, J., Stevens, M. P., and Gan, Y. H. (2008). Interleukin- 8 induction by Burkholderia pseudomallei can occur without Toll-like receptor signaling but requires a functional type III secretion system. J. Infect. Dis. 197, 1537-1547.

Hill, D. R., Ford, L., and Lalloo, D. G. (2006). Oral cholera vaccines: use in clinical practice. Lancet Infect. Dis. 6, 361-373.

Ho, M., Schollaardt, T., Smith, M. D., Perry, M. B., Brett, P. J., Chaowagul, W., and Bryan, L. E. (1997). Specificity and functional activity of antiBurkholderia pseudomallei polysaccharide antibodies. Infect. Immun. 65, 3648-3653.

Hoover, D. R., Saah, A. J., Bacellar, H., Phair, J., Detels, R., Anderson, R., Kaslow, R. A., and The Multicenter AIDS Cohort Study (1993). Clinical manifestations of AIDS in the era of Pneumocystis prophylaxis. N. Engl. J. Med. 329, 1922-1926.

Hoppe, I., Brenneke, B., Rohde, M., Kreft, A., Häußler, S., Reganzerrowski, A., and Steinmetz, I. (1999). Characterization of a murine model of melioidosis: comparison of different strains of mice. Infect. Immun. 67, 2891-2900

Hornick, R. B., and Eigelsbach, H. T. (1966). Aerogenic immunization of man with live Tularemia vaccine. Microbiol. Mol. Biol. Rev. 30, 532-538.

Howe, C., Sampath, A., and Spotnitz, M. (1971). The pseudomallei group: a review. J. Infect. Dis. 124, 598-606.

Iliukhin, V. I., Senina, T. V., Plekhanova, N. G., Antonov, V. A., Merinova, L. K., and Seimova, I. K. (2002). Burkholderia thailandensis: biological properties, identification and taxonomy. Mol. Gen. Mikrobiol. Virusol. 1, 7-11.

Inglesby, T. V., Dennis, D. T., Henderson, D. A., Bartlett, J. G., Ascher, M. S., Eitzen, E., Fine, A. D., Friedlander, A. M., Hauer, J., Koerner, J. F., McDade, J., Osterholm, M. T., O’Toole, T., Parker, G., Perl, T. M., Russell, P. K., Schoch-Spana, M., Tonat, K., and for the Working Group in Civilian Biodefense. (2000). Plague as a biological weapon: medical and public health management. JAMA 283, 2281-2290.

Inglesby, T. V., O’Toole, T., Henderson, D. A., Bartlett, J. G., Ascher,
M. S., Eitzen, E., Friedlander, A. M., Gerberding, J., Hauer, J., Hughes, J., McDade, J., Osterholm, M. T., Parker, G., Perl, T. M., Russell, P. K., Tonat, K., and for the Working Group in Civilian Biodefense. (2002). Anthrax as a biological weapon, 2002: updated recommendations for management. JAMA 287, 2236-2252.

Ivanoff, B., Levine, M. M., and Lambert, P. H. (1994). Vaccination against typhoid fever: present status. Bull. World Health Organ. 72, 957-971.

Janeway, C. A., and Medzhitov, R. (2002). Innate immune recognition. Annu. Rev. Immunol. 20, 197-216.

Janeway, C.A. Jr., Murphy, K., Travers, P., and Walport, M. (2008). Janeway's Immunobiology: T CellMediated Immunity, Chapter 8, 7th Edn. New York: Garland Science, 340-341.

Jones, A., DeShazer, D., and Woods, D. (1997). Identification and characterization of a two-component regulatory system involved in invasion of eukaryotic cells and heavymetal resistance in Burkholderia pseudomallei. Infect. Immun. 65, 4972-4977.

Jones, C. (2005). Vaccines based on the cell surface carbohydrates of pathogenic bacteria. An. Acad. Bras. Cienc. 77, 293-324.

Jones, S., Ellis, J., Russell, P., Griffin, K., and Oyston, P. (2002). Passive protection against Burkholderia pseudomallei infection in mice by monoclonal antibodies against capsular polysaccharide, lipopolysaccharide or proteins. J. Med. Microbiol. 51, 1055-1062.

Kanaphun, P., Thirawattanasuk, N., Suputtamongkol, Y., Naigowit, P., Dance, D. A., Smith, M. D., and White, N. J. (1993). Serology and carriage of Pseudomonas pseudomallei: a prospective study in 1000 hospitalized children in northeast Thailand. J. Infect. Dis. 167, 230-233.

Kaufmann, S. H. E., Hussey, G., and Lambert, P.-H. (2010). New vaccines for tuberculosis. Lancet 375, 2110-2119.

Ketheesan, N., Barnes, J. L., Ulett, G. C., VanGessel, H. J., Norton, R. E., Hirst, R. G., and LaBrooy, J. T. (2002). Demonstration of a cell-mediated immune response in melioidosis. J. Infect. Dis. 186, 286-289.

Lauw, F. N., Simpson, A. J., Prins, J. M., Smith, M. D., Kurimoto, M., van Deventer, S. J., Speelman, P., Chaowagul, W., White, N. J., and van der Poll, T. (1999). Elevated plasma concentrations of interferon
(IFN)-gamma and the IFN-gammainducing cytokines interleukin (IL)18 , IL-12, and IL-15 in severe melioidosis. J. Infect. Dis. 180, 1878-1885.

Lazzaroni, S. M., Barnes, J. L., Williams, N. L., Govan, B. L., Norton, R. E., LaBrooy, J. T., and Ketheesan, N. (2008). Seropositivity to Burkholderia pseudomallei does not reflect the development of cell-mediated immunity. Trans. R. Soc. Trop. Med. Hyg. 102, S66-S70.

Leakey, A. K., Ulett, G. C., and Hirst, R. G. (1998). BALB/c and C57Bl/6 mice infected with virulent Burkholderia pseudomallei provide contrasting animal models for the acute and chronic forms of human melioidosis. Microb. Pathog. 24, 269-275.

Lertmemongkolchai, G., Cai, G. Hunter, C. A., and Bancroft, G. J. (2001). Bystander activation of CD8+ $\mathrm{T}$ cells contributes to the rapid production of IFN-gamma in response to bacterial pathogens. $J$. Immunol. 166, 1097-1105.

Lever, M. S., Michelle, N., Anthony, J. S., Richard, J. B., and Andrew, J. H. S. (2009). Experimental acute respiratory Burkholderia pseudomallei infection in BALB/c mice. Int. J. Exp. Pathol. 90, 16-25.

Liljeqvist, S., and Ståhl, S. (1999). Production of recombinant subunit vaccines: protein immunogens, live delivery systems and nucleic acid vaccines. J. Biotechnol. 73, 1-33.

Limmathurotsakul, D., Chaowagul, W., Chierakul, W., Stepniewska, K., Maharjan, B., Wuthiekanun, V., White, N., Day, N., and Peakcock, S. (2006). Risk factors for recurrent melioidosis. Clin. Infect. Dis. 43 979-986.

Limmathurotsakul, D., Wuthiekanun, V., Chantratita, N., Wongsuvan, G., Thanwisai, A., Biaklang, M., Tumapa, S., Lee, S., Day, N. P. J., and Peacock, S. J. (2007). Simultaneous infection with more than one strain of Burkholderia pseudomalle is uncommon in human melioidosis. J. Clin. Microbiol. 45, 3830-3832.

Liu, B., Koo, G. C., Yap, E. H., Chua, K. L., and Gan, Y.-H. (2002). Model of differential susceptibility to mucosal Burkholderia pseudomallei infection. Infect. Immun. 70, 504-511.

Lu, S. (2009). Heterologous primeboost vaccination. Curr. Opin. Immunol. 21, 346-351.

Magalhaes, I., Sizemore, D. R., Ahmed, R. K., Mueller, S., Wehlin, L., Scanga, C., Weichold, F., Schirru, G., Pau, M. G., Goudsmit, J., KühlmannBerenzon, S., Spångberg, M., Andersson, J., Gaines, H., Thorstensson, R., Skeiky, Y. A. W., Sadoff, J., and Maeurer, M. (2008). rBCG induces strong antigen-specific $\mathrm{T}$ cell responses in Rhesus macaques in a prime-boost setting with an adenovirus 35 tuberculosis vaccine vector. PLoS ONE 3, e3790. doi: 10.1371/journal.pone.0003790

Maharjan, B., Chantratita, N., Vesaratchavest, M., Cheng, A., Wuthiekanun, V., Chierakul, W., Chaowagul, W., Day, N. P. J., and Peacock, S. J. (2005). Recurrent melioidosis in patients in northeast Thailand is frequently due to reinfection rather than relapse. J. Clin. Microbiol. 43, 6032-6034.

Martineau, A. R., Newton, S. M., Wilkinson, K. A., Kampmann, B., Hall, B. M., Nawroly, N., Packe, G. E., Davidson, R. N., Griffiths, C. J., and Wilkinson, R. J. (2007). Neutrophilmediated innate immune resistance to mycobacteria. J. Clin. Invest. 117, 1988-1994.

Matsuura, M., Kawahara, K., Ezaki, T., and Nakano, M. (1996). Biological activities of lipopolysaccharide of Burkholderia (Pseudomonas) pseudomallei. FEMS Microbiol. Lett. 137, 79-83.

McEniry, D. W., Gillespie, S. H., and Felmingham, D. (1988). Susceptibility of Pseudomonas pseudomallei to new beta-lactam and aminoglycoside antibiotics. J. Antimicrob. Chemother. 21, 171-175.

McShane, H., Pathan, A. A., Sander, C. R., Keating, S. M., Gilbert, S. C., Huygen, K., Fletcher, H. A., and Hill, A. V. S. (2004). Recombinant modified vaccinia virus Ankara expressing antigen 85A boosts BCG-primed and naturally acquired antimycobacterial immunity in humans. Nat. Med. 10, 1240-1244

Menard, L. C., Minns, L. A., Darche, S., Mielcarz, D. W., Foureau, D. M. Roos, D., Dzierszinski, F., Kasper, L. H., and Buzoni-Gatel, D. (2007). B cells amplify IFN-gamma production by $\mathrm{T}$ cells via a TNF-alphamediated mechanism. J. Immunol. 179, 4857-4866.

Mitus, A., Holloway, A., Evans, A. E., and Enders, J. F. (1962). Attenuated measles vaccine in children with acute leukemia. Am. J. Dis. Child. 103, 413-418.

Monafo, W. J., Haslam, D. B., Roberts, R. L., Zaki, S. R., Bellini, W. J., and Coffin, C. M. (1994). Disseminated measles infection after vaccination in a child with a congenital immunodeficiency. J. Pediatr. 124, 273-276. 
Mosmann, T. R., Cherwinski, H., Bond, M. W., Giedlin, M. A., and Coffman, R. L. (1986). Two types of murine helper $\mathrm{T}$ cell clone. I. Definition according to profiles of lymphokine activities and secreted proteins. J. Immunol. 136, 2348-2357.

Nelson, M., Prior, J. L., Lever, M. S., Jones, H. E., Atkins, T. P., and Titball, R. W. (2004). Evaluation of lipopolysaccharide and capsular polysaccharide as subunit vaccines against experimental melioidosis. $J$. Med. Microbiol. 53, 1177-1182.

Ngugi, S. A., Ventura, V. V., Qazi, O., Harding, S. V., Kitto, G. B., Estes, D. M., Dell, A., Titball, R. W., Atkins, T. P., Brown, K. A., Hitchen, P. G., and Prior, J. L. (2010). Lipopolysaccharide from Burkholderia thailandensis $\mathrm{E} 264$ provides protection in a murine model of melioidosis. Vaccine 28, 7551-7555.

Nieves, W., Heang, J., Asakrah, S., Höner zu Bentrup, K., Roy, C. J., and Morici, L. A. (2010). Immunospecific responses to bacterial elongation factor Tu during Burkholderia infection and immunization. PLoS ONE 17, e14361. doi: 10.1371/journal.pone.0014361

Novem, V., Shui, G., Wang, D., Bendt, A. K., Sim, S. H., Liu, Y., Thong, T. W., Sivalingam, S. P., Ooi, E. E., Wenk, M. R., and Tan, G. (2009). Structural and biological diversity of lipopolysaccharides from Burkholderia pseudomallei and Burkholderia thailandensis. Clin. Vaccine Immunol. 16, 1420-1428.

Perrone, L. A., Ahmad, A., Veguilla, V., Lu, X., Smith, G., Katz, J. M., Pushko, P., and Tumpey, T. M. (2009). Intranasal vaccination with 1918 influenza virus-like particles protects mice and ferrets from lethal 1918 and H5N1 influenza virus challenge. J. Virol. 83, 5726-5734.

Phair, J., Munoz, A., Detels, R., Kaslow, R., Rinaldo, C., and Saah, A. (1990). The risk of Pneumocystis carinii pneumonia among men infected with human immunodeficiency virus type 1. N. Engl. J. Med. $322,161-165$.

Piggott, J. A., and Hochholzer, L. (1970). Human melioidosis. A histopathologic study of acute and chronic melioidosis. Arch. Pathol. 90, 101-111.

Pilatz, S., Breitbach, K., Hein, N., Fehlhaber, B., Schulze, J., Brenneke, B., Eberl, L., and Steinmetz, I. (2006). Identification of Burkholderia pseudomallei genes required for the intracellular life cycle and in vivo virulence. Infect. Immun. 74 , 3576-3586.

Pirofski, L. A., and Casadevall, A. (1998). Use of licensed vaccines for active immunization of the immunocompromised host. Clin. Microbiol. Rev. 11, 1-26.

Plotkin, S. A. (2009). Vaccines: the fourth century. Clin. Vaccine Immunol. 16, 1709-1719.

Preston, M. J., Gerceker, A. A., Koles, N. L., Pollack, M., and Pier, G. B. (1997). Prophylactic and therapeutic efficacy of immunoglobulin G antibodies to Pseudomonas aeruginosa lipopolysaccharide against murine experimental corneal infection. Invest. Ophthalmol. Vis. Sci. 38, 1418-1425.

Puthucheary, S. D., Parasakthi, N., and Lee, M. K. (1992). Septicaemic melioidosis: a review of 50 cases from Malaysia. Trans. R. Soc. Trop. Med. Hyg. 86, 683-685.

Qazi, O., Prior, J. L., Judy, B. M., Whitlock, G. C., Kitto, G. B., Torres, A. G., Estes, D. M., and Brown, K. A. (2008). Sero-characterization of lipopolysaccharide from Burkholderia thailandensis. Trans. R. Soc. Trop. Med. Hyg. 102, S58-S60.

Radosevic, K., Wieland, C. W., Rodriguez, A., Weverling, G. J., Mintardjo, R., Gillissen, G., Vogels, R., Skeiky, Y. A. W., Hone, D. M., Sadoff, J. C., van der Poll, T., Havenga, M., and Goudsmit, J. (2007). Protective immune responses to a recombinant adenovirus type 35 tuberculosis vaccine in two mouse strains: CD4 and CD8 T-cell epitope mapping and role of gamma interferon. Infect. Immun. 75, 4105-4115.

Ramsay, S. C., Ketheesan, N., Norton, R., Watson, A. M., and LaBrooy, J. (2002). Peripheral blood lymphocyte subsets in acute human melioidosis. Eur. J. Clin. Microbiol. Infect. Dis. 21, 566-568.

Razak, C. E., Ismail, G., Embim, N., and Omar, O. (1986). Protection studies using whole cells and partially purified toxic material (PPTM) of Pseudomonas pseudomallei. Malays. Appl. Biol. 15, 105.

Renella, R., Perez, J. M., Chollet-Martin, S., Sarnacki, S., Fischer, A., Blanche, S., Casanova, J. L., and Picard, C. (2006). Burkholderia pseudomallei infection in chronic granulomatous disease. Eur. J. Pediatr. 165, 175-177.

Sander, C. R., Pathan, A. A., Beveridge, N. E. R., Poulton, I., Minassian, A., Alder, N., Van Wijgerden, J., Hill, A. V. S., Gleeson, F. V., Davies, R. J. O., Pasvol, G., and McShane, H. (2009). Safety and immunogenicity of a new tuberculosis vaccine, MVA85A, in Mycobacterium tuberculosis-infected individuals. Am. J. Respir. Crit. Care Med. 179, 724-733.
Santanirand, P., Harley, V., Dance, D., Drasar, B., and Bancroft, G. J. (1999). Obligatory role of gamma interferon for host survival in a murine model of infection with B. pseudomallei. Infect. Immun. 67 , 3593-3600.

Santanirand, P., Harley, V. S., Dance, D. A., Raynes, J. G., Drasar, B. S., and Bancroft, G. J. (1997). Interferongamma mediates host resistance in a murine model of melioidosis. Biochem. Soc. Trans. 25, 287 S.

Santosuosso, M., McCormick, S., Zhang, X., Zganiacz, A., and Xing, Z. (2006). Intranasal boosting with an adenovirus-vectored vaccine markedly enhances protection by parenteral Mycobacterium bovis BCG immunization against pulmonary tuberculosis. Infect. Immun. 74, 4634-4643.

Sarkar-Tyson, M., Smither, S. J., Harding, S. V., Atkins, T. P., and Titball, R. W. (2009). Protective efficacy of heat-inactivated $B$. thailandensis, B. mallei or B. pseudomallei against experimental melioidosis and glanders. Vaccine 27, 4447-4445.

Sarkar-Tyson, M., Thwaite, J. E., Harding, S. V., Smither, S. J., Oyston, P. C. F., Atkins, T. P., and Titball, R. W. (2007). Polysaccharides and virulence of Burkholderia pseudomallei. J. Med. Microbiol. 56, 1005-1010.

Scapini, P., Lapinet-Vera, J. A., Gasperini, S., Calzetti, F., Bazzoni, F., and Cassatella, M. A. (2000). The neutrophil as a cellular source of chemokines. Immunol. Rev. 177, 195-203.

Segal, A. W. (2004). How neutrophils kill microbes. Annu. Rev. Immunol. 23, 197-223.

Sharma, S. K., Mohan, A., and Kadhiravan, T. (2005). HIV-TB co-infection: epidemiology, diagnosis and management. Indian J. Med. Res. 121, 550-567.

Simpson, A. J., Smith, M. D., Weverling, G. J., Suputtamongkol, Y., Angus, B. J., Chaowagul, W., White, N. J., van Deventer, S. J., and Prins, J. M. (2000). Prognostic value of cytokine concentrations (tumor necrosis factor-alpha, interleukin6, and interleukin-10) and clinical parameters in severe melioidosis. $J$. Infect. Dis. 181, 621-625.

Simpson, A. J., Suputtamongkol, Y., Smith, M. D., Angus, B. J., Rajanuwong, A., Wuthiekanun, V., Howe, P. A., Walsh, A. L., Chaowagul, W., and White, N. J. (1999). Comparison of imipenem and ceftazidime as therapy for severe melioidosis. Clin. Infect. Dis. 29, 381-387.

Smith, M. D., Angus, B. J., Wuthiekanun, V., and White, N. J. (1997). Arabinose assimilation defines a nonvirulent biotype of Burkholderia pseudomallei. Infect. Immu. 65, 4319-4321.

Sprague, L. D., and Neubauer, H. (2004) Melioidosis in animals: a review on epizootiology, diagnosis and clinical presentation. J. Vet. Med. Ser. B Infect. Dis. Vet. Public Health 51, 305-320.

Stevens, M. P., Haque, A., Atkins, T., Hill, J., Wood, M. W., Easton, A., Nelson, M., Underwood-Fowler, C., Titball, R. W., Bancroft, G. J., and Galyov, E. E. (2004). Attenuated virulence and protective efficacy of a Burkholderia pseudomallei bsa type III secretion mutant in murine models of melioidosis. Microbiology 150, 2669-2676.

Su, Y.-C., Wan, K.-L., Mohamed, R., and Nathan, S. (2010). Immunization with the recombinant Burkholderia pseudomallei outer membrane protein Omp85 induces protective immunity in mice. Vaccine 28, 5005-5011.

Suputtamongkol, Y., Chaowagul, W., Chetchotisakd, P., Lertpatanasuwun, N., Intaranongpai, S., Ruchutrakool, T., Budhsarawong, D., Mootsikapun, P., Wuthiekanun, V., Teerawatasook, N., and Lulitanond, A. (1999) Risk factors for melioidosis and bacteremic melioidosis. Clin. Infect. Dis 29, 408-413.

Suputtamongkol, Y., Kwiatkowski, D., Dance, D. A., Chaowagul, W., and White, N. J. (1992). Tumor necrosis factor in septicemic melioidosis. J. Infect. Dis. 165, 561-564.

Tan, G.-Y. G., Liu, Y., Sivalingam, S. P., Sim, S.-H., Wang, D., Paucod, J.-C., Gauthier, Y., and Ooi, E.E. (2008). Burkholderia pseudomallei aerosol infection results in differential inflammatory responses in $\mathrm{BALB} / \mathrm{c}$ and $\mathrm{C} 57 \mathrm{Bl} / 6$ mice. J. Med. Microbiol. 57, 508-515.

Tanphaichitra, D., and Srimuang, S. (1984). Cellular immunity (T-cell subset using monoclonal antibody) in tuberculosis, melioidosis, pasteurellosis, penicilliosis; and role of levamisole and isoprinosine. Dev. Biol. Stand. 57, 117-123.

Taylor, P. R., Martinez-Pomares, L., Stacey, M., Lin, H. H., Brown, G. D., and Gordon, S. (2005). Macrophage receptors and immune recognition. Annu. Rev. Immunol. 23, 901-944.

Thomsen, A. R., Johansen, J., Marker, O., and Christensen, J. P. (1996). Exhaustion of CTL memory and recrudescence of viremia in lymphocytic choriomeningitis virus-infected MHC class II-deficient mice and B celldeficient mice. J. Immunol. 157, 3074-3080. 
Tippayawat, P., Saenwongsa, W., Mahawantung, J., Suwannasaen, D., Chetchotisakd, P., Limmathurotsakul, D., Peacock, S. J., Felgner, P. L., Atkins, H. S., Titball, R. W., Bancroft, G. J., and Lertmemongkolchai, G. (2009). Phenotypic and functional characterization of human memory $\mathrm{T}$ cell responses to Burkholderia pseudomallei. PLoS Negl. Trop. Dis. 3, e407. doi: 10.1371/journal.pntd.0000407

Titball, R. W. (2008). Vaccines against intracellular bacterial pathogens. Drug Discov. Today 13, 596-600.

Titball, R. W., Russell, P., Cuccui, J., Easton, A., Haque, A., Atkins, T., SarkarTyson, M., Harley, V., Wren, B., and Bancroft, G. J. (2008). Burkholderia pseudomallei: animal models of infection. Trans. R. Soc. Trop. Med. Hyg. 102, S111-S116.

Trakulsomboon, S., Pitt, T. L., and Dance, D. A. (1994). Molecular typing of Pseudomonas pseudomallei from imported primates in Britain. Vet. Rec. 135, 65-66.

Ulett, G. C., Ketheesan, N., and Hirst, R. G. (2000a). Cytokine gene expression in innately susceptible $\mathrm{BALB} / \mathrm{c}$ mice and relatively resistant $\mathrm{C} 57 \mathrm{BL} / 6$ mice during infection with virulent Burkholderia pseudomallei. Infect. Immun. 68, 2034-2042.

Ulett, G. C., Ketheesan, N., and Hirst, R. G. (2000b). Proinflammatory cytokine mRNA responses in experimental Burkholderia pseudomallei infection in mice. Acta Trop. 74, 229-234.

Utaisincharoen, P., Anuntagool, N., Arjcharoen, S., Lengwehasatit, I., Limposuwan, K., Chaisuriya, P., and Sirisinha, S. (2004). Burkholderia pseudomallei stimulates low interleukin- 8 production in the human lung epithelial cell line A549. Clin. Exp. Immunol. 138, 61-65.

Utaisincharoen, P., Tangthawornchaikul, N., Kespichayawattana, W., Chaisuriya, P., and Sirisinha, S. (2001). Burkholderia pseudomallei interferes with inducible nitric oxide synthase (iNOS) production: a possible mechanism of evading macrophage killing. Microbiol. Immunol. 45, 307-313.

Vasu, C., Vadivelu, J., and Puthucheary, S. D. (2003). The humoral immune response in melioidosis patients during therapy. Infection 31, 24-30.

Verreck, F. A. W., Vervenne, R. A. W., Kondova, I., van Kralingen, K. W., Remarque, E. J., Braskamp, G., van der Werff, N. M., Kersbergen, A., Ottenhoff, T. H. M., Heidt, P. J., Gilbert, S. C., Gicquel, B., Hill, A. V. S., Martin, H., McShane, H., and Thomas, A. W. (2009). MVA.85A boosting of BCG and an attenuated, phoP deficient M. tuberculosis vaccine both show protective efficacy against tuberculosis in Rhesus macaques. PLoS ONE 4, e5264. doi: 10.1371/journal.pone. 0005264

Wand, M., Muller, C., Titball, R., and Michell, S. (2011). Macrophage and Galleria mellonella infection models reflect the virulence of naturally occurring isolates of B. pseudomallei, B. thailandensis and B. oklahomensis. BMC Microbiol. 11, 11. doi: 10.1186/1471-2180-11-11

Wells, T. J., Tree, J. J., Ulett, G. C., and Schembri, M. A. (2007). Autotransporter proteins: novel targets at the bacterial cell surface. FEMS Microbiol. Lett. 274, 163-172.

White, N. (2003). Melioidosis. Lancet 361, 1715-1722.

Wiersinga, W., van der Poll, T., White, N., Day, N., and Peacock, S. (2006). Melioidosis: insights into the pathogenicity of Burkholderia pseudomallei. Nat. Rev. Microbiol. 4, 272-282.

Wiersinga, W. J., Dessing, M. C., Kager P. A., Cheng, A. C., Limmathurotsakul, D., Day, N. P., Dondorp, A. M., van der Poll, T., and Peacock, S. J. (2007a). High-throughput mRNA profiling characterizes the expression of inflammatory molecules in sepsis caused by Burkholderia pseudomallei. Infect. Immun. 75 , 3074-3079.

Wiersinga, W. J., Wieland, C. W., Dessing, M. C., Chantratita, N., Cheng, A. C., Limmathurotsakul, D., Chierakul, W., Leendertse, M., Florquin, S., de Vos, A. F.,White, N., Dondorp, A. M., Day, N. P., Peacock, S. J., and van der Poll, T. (2007b). Tolllike receptor 2 impairs host defense in Gram-negative sepsis caused by Burkholderia pseudomallei (melioidosis). PLoS Med. 4, e248. doi: 10.1371/journal.pmed.0040248

Wiersinga, W. J., Wieland, C. W., van der Windt, G. J. W., de Boer, A., Florquin, S., Dondorp, A., Day, N. P., Peacock, S. J., and van der Poll, T. (2007c). Endogenous interleukin18 improves the early antimicrobial host response in severe melioidosis. 75, 3739-3746.

Wiersinga, W. J., and van der Poll, T. (2009). Immunity to Burkholderia pseudomallei. Curr. Opin. Infect. Dis. 22, 102-108.
Wiersinga, W. J., Wieland, C. W., Roelofs, J. J. T. H., and van der Poll, T. (2008). MyD88 dependent signaling contributes to protective host defense against Burkholderia pseudomallei. PLoS ONE 3, e3494. doi: 10.1371/journal.pone. 0003494

Williamson, E. D. (2009). Plague. Vaccine 27, D56-D60.

Wong, K. T., Puthucheary, S. D., and Vadivelu, J. (1995). The histopathology of human melioidosis. Histopathology 26, 51-55.

Conflict of Interest Statement: The authors declare that the research was conducted in the absence of any commercial or financial relationships that could be construed as a potential conflict of interest.

Received: 11 July 2011; accepted: 06 September 2011; published online: 27 September 2011.

Citation: Patel N, Conejero L, De Reynal $M$, Easton A, Bancroft $G J$ and Titball RW (2011) Development of vaccines against Burkholderia pseudomallei. Front. Microbio. 2:198. doi: 10.3389/fmicb.2011.00198

This article was submitted to Frontiers in Cellular and Infection Microbiology, a specialty of Frontiers in Microbiology. Copyright (c) 2011 Patel, Conejero, De Reynal, Easton, Bancroft and Titball. This is an open-access article subject to a non-exclusive license between the authors and Frontiers Media SA, which permits use, distribution and reproduction in other forums, provided the original authors and source are credited and other Frontiers conditions are complied with. 